\title{
WestVirginiaUniversity
}

THE RESEARCH REPOSITORY @ WVU

Graduate Theses, Dissertations, and Problem Reports

2021

\section{Exploring the Impact of Incentives on Management Behavior}

Chen Zhao

West Virginia University, chzhao@mix.wvu.edu

Follow this and additional works at: https://researchrepository.wvu.edu/etd

Part of the Accounting Commons

\section{Recommended Citation}

Zhao, Chen, "Exploring the Impact of Incentives on Management Behavior" (2021). Graduate Theses, Dissertations, and Problem Reports. 8330.

https://researchrepository.wvu.edu/etd/8330

This Dissertation is protected by copyright and/or related rights. It has been brought to you by the The Research Repository @ WVU with permission from the rights-holder(s). You are free to use this Dissertation in any way that is permitted by the copyright and related rights legislation that applies to your use. For other uses you must obtain permission from the rights-holder(s) directly, unless additional rights are indicated by a Creative Commons license in the record and/ or on the work itself. This Dissertation has been accepted for inclusion in WVU Graduate Theses, Dissertations, and Problem Reports collection by an authorized administrator of The Research Repository @ WVU.

For more information, please contact researchrepository@mail.wvu.edu. 


\title{
Exploring the Impact of Incentives on Management Behavior
}

\author{
Chen Zhao \\ Dissertation Submitted \\ To the John Chambers College of Business and Economics \\ At West Virginia University \\ In partial fulfillment of the requirements for the degree of \\ Doctor of Philosophy in \\ Accounting \\ Richard B. Dull, Ph.D., Chair \\ Lauren A. Cooper, Ph.D. \\ Trevor L. Sorensen, Ph.D. \\ Paul J. Speaker, Ph.D. \\ Department of Accounting \\ Morgantown, West Virginia \\ 2021
}

Keywords: firm life cycle, disclosure quality, fraud, nonprofit rating, CEO compensation

(C) 2021 Chen Zhao 


\begin{abstract}
Exploring the Impact of Incentives on Management Behavior
\end{abstract}

\title{
Chen Zhao
}

This dissertation is comprised of three studies that examine the impact of incentives on management behavior to complement agency problems literature. The first paper studies whether incentives associated with firm life cycle stages impact management disclosure quality. The second paper explores these incentives more deeply and investigates whether the likelihood of fraud is different across life cycle stages. The third paper examines whether rating agencies play a role in alleviating agency problems in nonprofit organizations by increasing public exposure and reducing information asymmetry.

Study one examines the relationship between firms' life cycle stages and disclosure quality. Life cycle stages are measured following Dickinson (2011), who recently redefined firm life cycle in terms of firms' operating, investing, and financing cash flows. The analysis provides evidence that disclosure quality is significantly different across firm life cycle stages. Specifically, firms in the introduction, growth, and mature life cycle stages have higher disclosure quality than firms in other life cycle stages. Another test observes significant differences in disclosure quality within life cycle stages based on firms' profitability and size. This study contributes to the financial disclosure literature by documenting firms' life cycle stage as a significant determinant of disclosure quality.

In study two, the incentives associated with life cycle stages are explored to a greater extent, and this study investigates whether firm life cycle is associated with fraud. According to fraud theory, incentives and opportunities are important factors that lead to fraud (Dorminey, Fleming, Kranacher, and Riley 2012). Following Dickinson (2011), this paper uses cash flow patterns as a proxy for life cycle stages. Firms in different life cycle stages have different combinations of signs of cash flows, so the incentives and opportunities are likely to be different. Therefore, we expect that the likelihood of committing fraud is different across life cycle stages. We identify 182 fraud firms with available data from the AAER database and utilize a 4-to-1 matched sample, as well as the overall sample in our analysis. The paper finds that introduction stage is positively associated with fraud, while mature firms are negatively associated with fraud.

Study three investigates whether nonprofit rating availability is negatively associated with CEO pay-to-performance sensitivity. Prior studies on agency theory suggest that agency problems exist in both for-profit organizations and nonprofit organizations, and research on agency problems for nonprofit organizations focuses on the role of nonprofit board. However, some other studies point out that there are limitations of the monitoring role of the board. On the other hand, donors provide funds to nonprofit organizations, and they have more substantial incentives to monitor nonprofit organizations. Balsam and Harris (2014) and Balsam and Harris (2018) find evidence that donors look unfavorably at higher compensation. Therefore, if monitoring of donors is available, it is likely that CEO compensation will be lower. Research finds that donors use rating information to make donation decisions (Gordon, Knock, and Neely 2009; Harris and Neely 2016). Therefore, charity rating agencies provide a tool for donors to monitor nonprofit organizations. 
Using data from Charity Navigator and nonprofit organization tax forms, this study finds that charity rating availability is negatively associated with CEO pay-to-performance sensitivity for nonprofit organizations. 


\section{DEDICATION}

I dedicate my dissertation work to my family. A special feeling of gratitude to my dear parents, who provided me with endless support to continue my study. Also, much love for my husband, Feiyu, who encouraged me and supported me during all the ups and downs of this Ph.D. journey. I also dedicate my dissertation to my loving children, Elsa and Edward. You have made me stronger, better, and more fulfilled than I could have ever imagined. I love you both to the moon and back. 


\section{ACKNOWLEDGEMENT}

I would like to give special thanks to my dissertation chair, Dr. Richard B. Dull, for his continuous support on my dissertation. He generously shared his nonprofit database for me to complete this dissertation and opened the door of research on nonprofit organizations for me. His mentorship during my doctoral studies guided me toward the path to becoming an independent and successful researcher.

I would also like to extend a special thank you to my dissertation committee members, Dr. Trevor L. Sorensen, who has mentored me all through my doctoral studies, Dr. Lauren A. Cooper, for all the comments, suggestions, and guidance to improve my dissertation, and Dr. Paul J. Speaker, for all your supports during my graduate studies.

More thanks will be given to our department chair, Dr. Richard A. Riley, for his mentorship on my dissertation and his guidance and efforts to expand my research in the fraudulent research area.

Special thanks to Dr. D. Kip Holderness Jr., for all his supports during my doctoral studies and his advice as our Ph.D. coordinator.

I would also like to thank the other Ph.D. students in my cohort, Ali and Marie, for continuous supports and encouragement in my study and life. It could not have been such a fun journey without either of you.

Finally, to my dear friends in Morgantown, for all the unwavering supports during my studies. 


\section{Table of Contents}

CHAPTER ONE: INTRODUCTION ................................................................................... 1

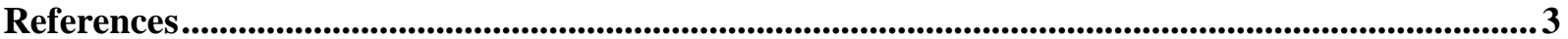

CHAPTER TWO: FIRM LIFE CYCLE AND DISCLOSURE QUALITY .......................... 5

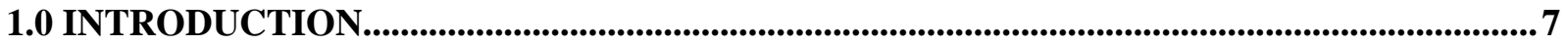

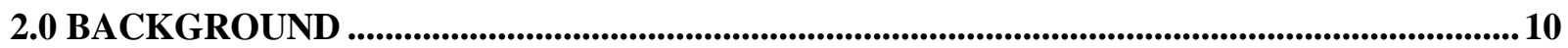

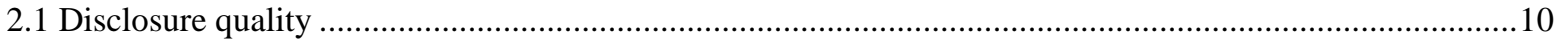

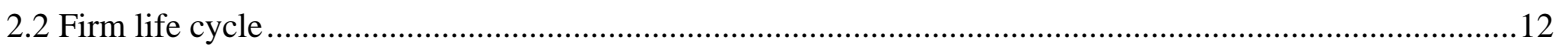

3.0 HYPOTHESIS DEVELOPMENT ....................................................................................................... 14

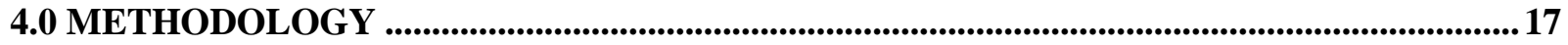

5.0 SAMPLES AND EMPIRICAL RESULTS.................................................................................20

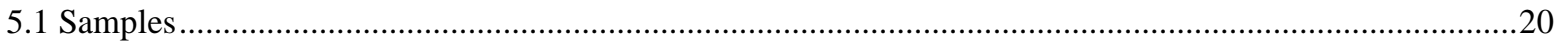

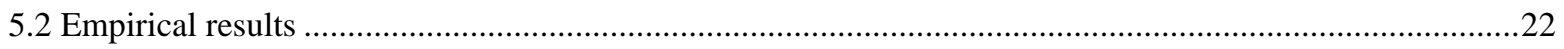

6.0 CONCLUSION .............................................................................................................................................23

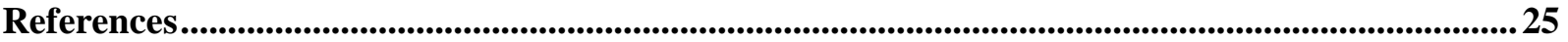

CHAPTER THREE: FIRM LIFE CYCLE AND FRAUD ................................................ 35

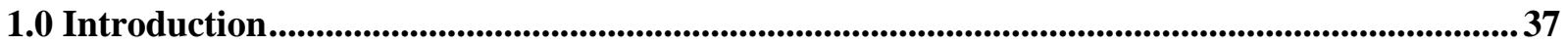

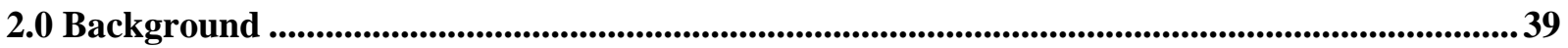

3.0 Hypotheses development ..........................................................................................................................44

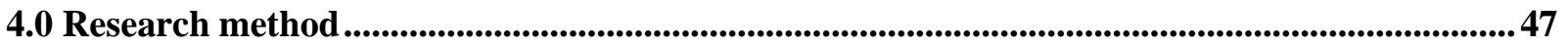

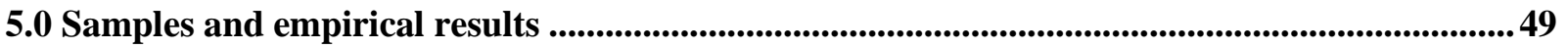

6.0 Summary and conclusions........................................................................................................................53

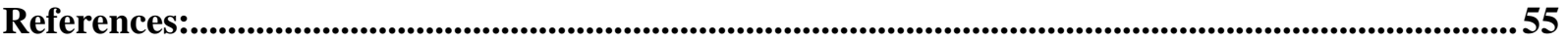

CHAPTER FOUR: NONPROFIT RATINGS AND PAY-TO-PERFORMANCE

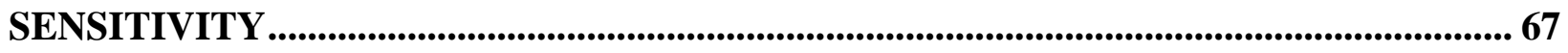

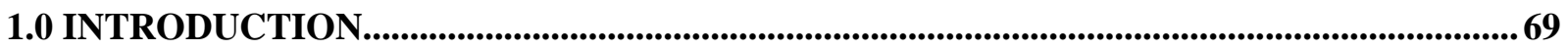

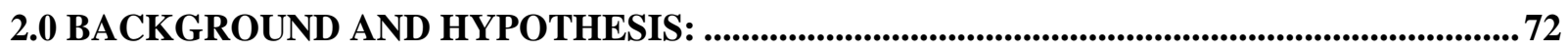

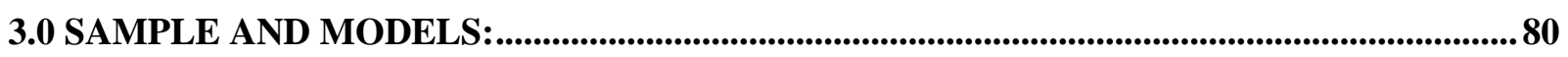

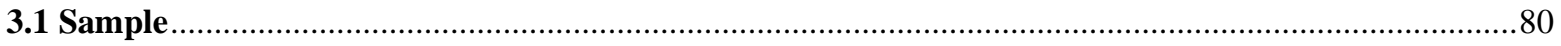

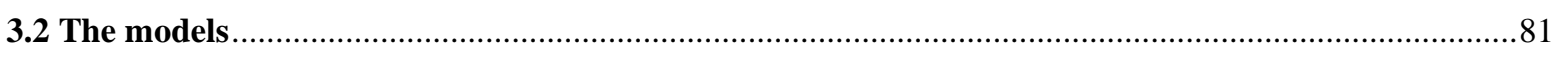

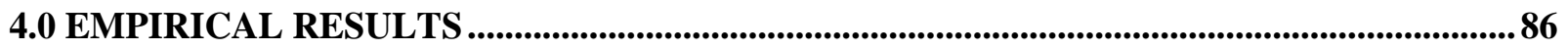

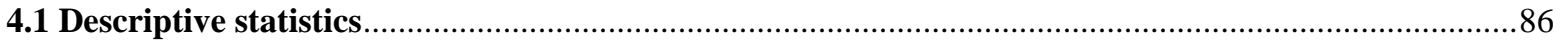

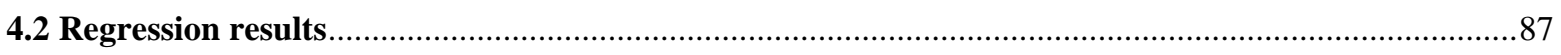

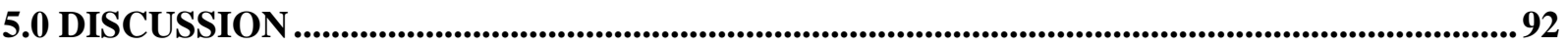

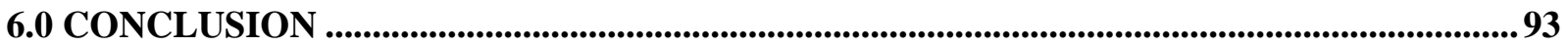




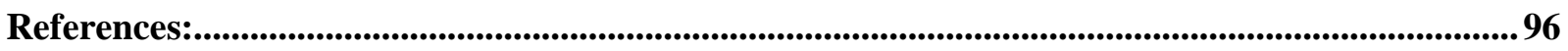

Appendix -How to obtain historical ratings data from Charity Navigator API ............................99 


\section{CHAPTER ONE: INTRODUCTION}

Agency theory states that managers might not behave in a way to maximize the welfare of the principal because ownership and management of the firms are separated (Jensen and Meckling 1976). The firms' owners aim to maximize the firm's value in the long run so that they could boost their wealth through their holdings, while management are more concerned about their careers so they may focus on short-term performance or be more or less risk-taking when making decisions. Practices have been developed to alleviate agency problems. For example, even though owners do not have direct access to corporate governance, they monitor management behavior through the board and auditors. Some management behaviors are beneficial to the firms, while others are unethical and sometimes illegal. Investigating the impacts of incentives on management behavior is of interest to society because unethical or illegal behaviors can be detected or predicted more efficiently if these impacts are acknowledged. Therefore, this dissertation explores how incentives from different situations will impact management behaviors in both for-profit and nonprofit organizations.

The first paper examines whether disclosure quality is different across firm life cycle stages. One of the main issues in public firms is information asymmetry between investors and management. Managers are engaged in day-to-day operations, and they have the best knowledge of how the firm is operating financially and non-financially, as well as the firm's growth potential and risks. However, investors do not participate in the firm's operations, and they acquire information from the analysts and the firm's public disclosures. Even though analysts attend earnings conference calls and communicate with the firm, they rely primarily on public disclosures. Therefore, the quality of disclosures of the firm is essential to both analysts and investors. However, since higher disclosure quality requires management effort (Hui and Matsunaga 2015), managers may not disclose high-quality information if they do not have incentives. Firms at different life cycle stages have different characteristics and goals (Spence 1977, 1979, 1981; Wernerfelt 1985; Jovanovic and MacDonald 1994; Dickinson 2011). Therefore, manager incentives may be different, and disclosure quality will likely differ across firm life cycle stages. Identifying firm disclosure quality using life cycle stages allows investors to make better investment decisions and analysts to provide more accurate estimations.

The second paper in this dissertation studies whether firm life cycle is associated with fraud. Disclosure quality lies in the grey area of regulation because providing low disclosure quality might be unethical but not illegal. However, if the firm is facing severe financial pressure, managers have strong incentives to manage earnings, potentially to the point that they commit fraud (Hogan, Rezaee, Riley and Velury 2008; Armstrong, Jagolinzer, and Larcker 2010; Koh, Matsumoto, and Rajgopal 2008). Fraud is a costly problem in the business world, and researchers have been working to explore how to detect, predict and prevent fraud (Hogan et al. 2008; Bell and Carcello 2000; Dechow, Sloan and Sweeney 1996; and Farber 2005). However, no prior research has studied the impact of life cycle stages on the likelihood of fraud. If the incentives within specific life cycles become strong enough, managers may commit fraud. Therefore, this paper examines whether firm life cycle stages provide different incentives to managers and whether the likelihood of committing fraud is different across life cycle stages.

Like commercial firms, nonprofit organizations also face agency problems. Nonprofit organizations receive funding from donors and government grants. The donors do not participate in operations, and they rely on the directors of the nonprofit organizations to spend the funding on 
organization missions. Since the donors are fund providers, they have substantial incentives to monitor nonprofit organization operations. However, their monitoring role is limited by their ability to acquire and interpret the information disclosed by the nonprofit organizations, such as the tax forms. Charity rating agencies provide nonprofit ratings based on the analyses on nonprofit characteristics, and the rating information is easy, accessible, and understandable to donors. Prior research also finds evidence that donors dislike high compensation (Balsam and Harris 2014; Balsam and Harris 2018). donors use rating information to make decisions (Gordon, Evans, and Nanda 2009; Harris and Neely 2016). Therefore, it is likely that charity ratings serve as the tools for donors to monitor nonprofit organizations. Results show that rating availability is negatively associated with pay-to-performance sensitivity for nonprofit organizations, and higher overall and financial rating scores are associated with lower pay-to-performance sensitivity. This implies that donors likely play a monitoring role on nonprofit organizations through charity rating agencies. 


\section{References}

Aggarwal, R. K., M. E. Evans, and D. Nanda. 2012. Nonprofit boards : Size , performance and managerial incentives \$. Journal of Accounting and Economics 53 (1-2): 466-487.

Armstrong, C. S., A. D. Jagolinzer, and D. F. Larcker. 2010. Chief Executive Officer Equity Incentives and Accounting Irregularities. Journal of Accounting Research 48 (2): 225-271.

Balsam, S., and E. E. Harris. 2014. The Impact of CEO Compensation on Nonprofit Donations. The Accounting Review 89 (2): 425-450.

- 2018. Nonprofit executive incentive pay. Review of Accounting Studies 23: 1665-1714.

Dickinson, V. 2011. Cash flow patterns as a proxy for firm life cycle. The Accounting Review 86 (6): 1969-1994.

Fama, E. F., and M. C. Jensen. 1983. Separation of ownership and control. Journal of Law \& Economics XXVI: 301-325.

Gordon, T. P., C. L. Knock, and D. G. Neely. 2009. The role of rating agencies in the market for charitable contributions : An empirical test. Journal of Accounting and Public Policy 28 (6): 469-484.

Harris, E. E., and D. G. Neely. 2016. Multiple Information Signals in the Market for Charitable Donations. Contemporary Accounting Research 33 (3): 989-1012.

Hogan, C. E., Z. Rezaee, R. A. Riley, and U. K. Velury. 2008. Financial statement fraud: Insights from the academic literature. Auditing: A Journal of Practice \& Theory 27 (2): $231-252$.

Hui, K. W., and S. R. Matsunaga. 2015. Are CEOs and CFOs rewarded for disclosure quality? Accounting Review 90 (3): 1013-1047.

Jensen, M. C., and W. H. Meckling. 1976. Theory of the firm: Managerial behavior, agency costs and ownership structure. In Corporate Governance: Values, Ethics and Leadership, 3:77132.

Jovanovic, B. and MacDonald, G.M., 1994. The life cycle of a competitive industry. Journal of Political Economy, 102(2): 322-347.

Koh, K., D. A. Matsumoto, and S. Rajgopal. 2008. Meeting or beating analyst expectations in the post-scandals world: Changes in stock market rewards and managerial actions. Contemporary Accounting Research 25 (4): 1067-1098. 
Lowell, S., B. Trelstad, and B. Meeham. 2005. the ratings game. Stanford Social Innovation Review 3 (2): 38-45.

Preston, A. E. 1989. The nonprofit worker in a for-profit world. Journal of Labor Economics 7 (4): $438-463$.

Spence, A.M. 1977. Entry, capacity, investment and oligopolistic pricing. The Bell Journal of Economics: 534-544.

Spence, A.M. 1979. Investment strategy and growth in a new market. J. Reprints Antitrust L. \& Econ. 10: 345.

Spence, A.M. 1981. The learning curve and competition. The Bell Journal of Economics: 49-70.

Trompeter, G. M., T. D. Carpenter, N. Desai, K. L. Jones, and R. A. Riley. 2013. A synthesis of fraud-related research. Auditing: A Journal of Practice \& Theory 32 (1): 287-321.

Wernerfelt, B. 1985. The dynamics of prices and market shares over the product life cycle. Management Science 31 (8): 928-939. 


\title{
CHAPTER TWO: FIRM LIFE CYCLE AND DISCLOSURE QUALITY
}

\author{
Lauren A. Cooper * \\ John Chambers College of Business and Economics \\ West Virginia University \\ lauren.cooper@mail.wvu.edu \\ Trevor L. Sorensen \\ John Chambers College of Business and Economics \\ West Virginia University \\ trevor.sorensen@mail.wvu.edu
}

Chen Zhao

John Chambers College of Business and Economics

West Virginia University

chzhao@mix.wvu.edu

*Corresponding author. We express our thanks for valuable feedback provided by conference participants at the AAA Mid-Atlantic Region Meeting Doctoral Consortium. 


\begin{abstract}
We examine the relation between firms' life cycle stages and disclosure quality. We measure life cycle stages following Dickinson (2011), who redefined firm life cycle in terms of firms' operating, investing, and financing cash flows. We find that disclosure quality is significantly different across firm life cycle stages. Specifically, firms in the growth and mature life cycle stages have higher disclosure quality than firms in other life cycle stages. Our study contributes to the financial disclosure literature by documenting firms' life cycle stage as a significant determinant of disclosure quality.
\end{abstract}

Keywords: Disclosure quality, life cycle, analyst forecasts 


\subsection{INTRODUCTION}

Public firm disclosures are under the Security and Exchange Commission (SEC) regulation and serve as a tool of communication between firms and their investors. Disclosure quality is the effectiveness of this communication (Hui and Matsunaga 2015). If firm information is disclosed thoroughly, accurately, and in a timely manner, disclosure quality will be higher, and information asymmetry between firms and investors will be reduced. The content, accuracy, and timeliness of disclosures are under the control of management, which has various incentives to manipulate whether to disclose, what to disclose, and when to disclose specific information to parties outside the firm.

To further examine management incentives to disclose information, we study firm life cycle theory to find potential relationships between firms' life cycle stages and disclosure quality. ${ }^{1}$ Firm life cycle theory states that firms transition between life cycle stages and experience an inverted U-shaped curve based on growth, with firms in the introduction and decline stages at the bottom of the curve and growth and mature stages at the top (Anthony and Ramesh 1992; and Dickinson 2011). While the general expectation may be for a firm to transition between the stages in a set order, many factors such as mergers or new product lines may cause a firm to move back and forth between the life cycle stages multiple times. Given that firms in different life cycle stages emphasize operating, investing, and financing cash flows differently, their incentives and subsequent behavior also diverge (Myers 1977; and Jenkins et al. 2004). Consistent with this claim, Hasan, Al-Hadi, Taylor, and Richardson (2016) find that firms' tax avoidance behavior differs

\footnotetext{
${ }^{1}$ Following Gort and Klepper (1982), Dickinson (2011) separates the firms into five life cycle stages: (1) introduction, (2) growth, (3) mature, (4) shake-out, and (5) decline.
} 
across life cycle stages, while Haribar and Yehuda (2015) document that the mispricing of cash flows and accruals also differ across life cycle stages. It is also possible that firms' disclosure quality is different across life cycle stages, given that firms' ability to provide high-quality disclosures and their incentives to do so are likely to vary depending on their current life cycle stage.

Following Hui and Mastunaga (2015), we obtain disclosure quality residuals from an OLS regression analysis. The model includes variables that potentially impact firms' disclosure quality, and the residuals indicate what is not explained in the model. Because this paper focuses on management behavior, we follow Hui and Mastunaga (2015) and focus on the disclosure quality residuals because it represents management's impact on disclosure quality. We further present how management's effect on disclosure quality is different across life cycle stages by showing the mean disclosure quality residuals across life cycle stages. We also include in our analysis how future disclosure quality is impacted by current life cycle stages and show the mean disclosure quality residuals are different for the next coming one and two years. Overall, our result shows that introduction, shake-out, and decline firms have negative disclosure quality residuals, while growth and mature firms have positive disclosure quality residuals. The results imply that growth firms and mature firms have higher disclosure quality than the other three groups of firms. Future disclosure quality analysis shows that disclosure quality increases one or two years following the identification of growth or mature firms, and disclosure quality decreases one or two years following the identification of introduction or decline firms.

This study contributes to the literature in the following ways. First, it extends the literature examining the disclosure quality of U.S. firms. We document that life cycle stage is a significant determinant of disclosure quality. In particular, we find that firms in the growth and mature stages 
have higher quality disclosures than other firm groups. Accordingly, our study expands our understanding of how firms' incentives to disclose information, based on their life cycle stage, impacts disclosure quality. Given that disclosure quality affects the accuracy of firms' valuations, our findings should be informative to investors and analysts. Even though information asymmetry between management and parties outside the firm cannot be eliminated completely, indicators of disclosure quality based on firms' life cycle stage can help investors and analysts determine how much reliance they can place on corporate disclosures in their valuation process.

Our study also contributes to the literature examining the interaction between disclosure quality and cost of capital. Evidence from prior literature indicates that higher disclosure quality reduces firms' cost of capital (Botosan 1997; Botosan and Plumlee 2001; Gietzmann and Ireland 2005; Lambert et al. 2007; Francis, Nanda and Olsson 2008). In the context of firm life cycle stages and cost of capital, Hasan, Hossain, and Habib (2015) find that cost of capital is higher for firms in the introduction and decline stages and lower for those in the growth and mature stages. Our results show that growth and mature firms have higher disclosure quality, which corresponds to the prior literature that there is a negative correlation between disclosure quality and cost of capital.

Our results also have practical implications for financial report users. Research has found that disclosure quality is associated with analyst behaviors (Lang and Lundholm 1996), cost of capital (Botosan 1997; Botosan and Plumlee 2001; Gietzmann and Ireland 2005) and litigation risks (Francis et al. 1994). Research also finds that investors use disclosures to make investment decisions (Gao 2010) and disclosure quality is associated with stock prices (Easley and O'Hara 2004). Therefore, by identifying additional variables associated with disclosure quality, this paper can help financial report users make wiser decisions. 
The rest of the paper is presented as follows. Section 2 provides the background of disclosure quality and firm life cycles. The hypotheses are developed in section 3 . Section 4 outlines the sample and methodology. The regression results are discussed in section 5, while section 6 concludes.

\subsection{BACKGROUND}

\subsection{Disclosure quality}

Disclosure quality is generally defined as the effectiveness of a firms' communication with investors (Hui and Matsunaga 2015), and disclosures are one of the primary tools for corporate communications with other parties. Potential and current investors rely on disclosures to make investment decisions (Gao 2010). As evidence of this, disclosure quality is highly correlated with stock prices. Easley and O'Hara (2004) find that information from public firms' impact stock prices, and specifically, investors demand a higher return to hold stocks with more private information. Healy et al. (1999) also provide evidence that an increase in disclosure quality is accompanied by an increase in firm stock returns, institutional ownership, and analyst following. In their literature review, Healy and Palepu (2001) examine the forces that give rise to a demand for disclosure and find that information asymmetry and agency conflicts between managers and outside investors drive the demand for financial reporting and disclosure. Theory also suggests that higher quality disclosures lead to lower information asymmetry between investors and the corporation (Lang and Lundholm 1996), making the market more efficient, and resulting in increased liquidity in equity markets (Welker 1995; Healy et al. 1999; Leuz and Verrecchia 2000; Healy and Palepu 2001). Prior research also finds that higher-quality disclosures reduce litigation risk (Francis et al. 1994) and improve investment efficiency (Bushman and Smith 2001; Biddle and Hilary 2006). Drake et al. (2009) study the mispricing of accruals and cash flows and find that 
the mispricing is higher for firms with lower disclosure quality, i.e., lower AIMR scores. Overall, it appears that higher disclosure quality can reduce information asymmetry and can be beneficial to the market.

In addition to serving as a communication tool, disclosure quality can also impact a firms’ cost of capital. Cost of capital is the rate of return required by investors and is associated with investing risks (Easley and O’Hara 2004; Lambert et al. 2007). If a firm or project involves higher risk (i.e., higher volatility in cash flows), investors will require a higher rate of return to offset the risk, thereby resulting in a higher cost of capital. Prior research finds evidence that higher-quality disclosures decrease the cost of capital (Francis 2008). Also, using a theoretical framework, Lambert et al. (2007) prove that high-quality information decreases a firm's cost of capital. Specifically, Lambert et al. (2007) use the Capital Asset Pricing Model as the primary model for firm valuation and find evidence that higher-quality disclosures reduce the assessed variance of a firm's cash flow and affect the cash flow assessed covariance with that of other firms. While it seems apparent that higher disclosure quality reduces cost of capital, prior research has found that other factors moderate the relationship between disclosure quality and cost of capital. The negative relationship only holds for specific subsets of firms. For example, Botosan (1997) finds that higher disclosure reduces a firms' cost of capital, but just for firms with low analyst following. Gietzmann and Ireland (2005) control for accounting policy choice and find that the negative relationship between disclosure quality and cost of capital is only significant for "aggressive" firms (i.e., those with positive discretionary accruals). In an experimental setting, Barron and Qu (2014) find that high-quality public disclosures lead to higher price efficiency and lower cost of capital when information asymmetry is high. Overall, higher disclosure quality is expected to reduce the cost of capital, but differing firm situations can alter that relationship. 
Another interesting aspect to consider about disclosure quality is that management determines what information to disclose. High-quality disclosures require management effort (Hui and Matsunaga 2015), which means that management incentives can impact disclosure quality. Hui and Matsunaga (2015) study the impact of CEO/CFO compensation on disclosure quality and find that changes in disclosure quality are positively associated with changes in CEO and CFO's annual bonus and that the relation is more robust for growth firms.

\subsection{Firm life cycle}

Firm life cycle theory suggests that firms transition between different life cycle stages and the current life stage is determined by various internal and external factors, such as strategy choices, managerial ability, and competitive environments (Dickinson 2011). On the other hand, the firm life cycle stage can also impact firms' behaviors because they are under different situations and the incentives vary. For example, Faff et al. (2016) find that firms make fewer investments and issue less equity as they become more mature, while debt issuance and cash holding increase in the introduction and growth stages and decrease in the mature and shake-out/decline stages of firms' life cycle. Habib and Hasan (2017) study firm risk-taking and find out that corporate risk-taking, as indicated by a fluctuation of return on investment and return on equity, is higher during the introduction and decline stages but lower during the maturity stage. Dividend payout activities are also different among firm life cycles (DeAngelo et al. 2006; Banyi and Kahle 2014), and the likelihood of firms paying dividends is higher as firms grow. Moreover, Hasan et al. (2017) study tax avoidance and firm life cycle and find a U-shaped pattern in tax avoidance outcomes across the various life cycle stages, with introduction and decline firms conducting more tax avoidance.

In addition to the firm life cycle's effect on corporate incentives and decisions, investors' perceptions and market reactions also differ across firm life cycles. For example, Hasan et al. (2014) 
find that cost of capital is higher in the introduction and decline stages and lower in the growth and mature stages. Market-to-book ratio indicates the market's perceptions of firms' growth, and Dickinson (2011) shows that the market-to-book ratio is higher for introduction and growth firms while lower for shake-out and decline firms. Anthony and Ramesh (1992) also find that the firm life cycle is a moderator for the stock market's response to sales growth and capital investment.

Firms have different incentives when they are at different life cycle stages. According to Myers (1977), firm value has two components: assets in place and growth options. Existing assets, operations, and investments indicate current cash flows, and potential growth options and decisions impact future cash flows. The combinations of the two variables are different across firm life cycle stages. For example, introduction firms have fewer assets (Dickinson 2011) but have more growth options. Thus introduction firms would invest more to capture their growth potentials. On the other hand, mature firms are larger in assets (Dickinson 2011) but do not have as many growth opportunities. As a result, firms use different strategies to maximize their value at different life cycle stages. Moreover, their strategies will impact their secondary incentives. For example, growth firms need to finance more to meet their investment needs. In fact, Dickinson (2011) finds that the average leverage of growth firms is the largest among all the life cycle stages, which indicates larger amounts of borrowing by growth firms. Thus, growth firms have more significant incentives to lower their cost of capital. Considering this evidence that firms at different life cycle stages have different motivations and behave accordingly, it is likely that the disclosure quality among life cycle stages will also differ.

Prior research has found that firm life cycle is associated with financial reporting quality. Suberi, Hus, and Wyatt (2012) find that mature firms have more persistent earnings. Firms' beating or meeting benchmarks behavior is also different across life cycle stages (Choi, Choi, and Lee 
2016). However, no prior research has studied the impact of firm life cycle on disclosure quality. Since life cycle is associated with financial reporting quality, it is of interest to study how life cycle impacts disclosure quality.

\subsection{HYPOTHESIS DEVELOPMENT}

Disclosure quality is highly impacted by management incentives. Managers can choose to disclose or withhold information for different purposes. For example, Healy and Palepu (2001) point out that management tends to withhold bad news in order to attract more investors. Verrecchia (2001) summarizes what is suggested from prior research that management would disclose more information when trying to maximize the current market capitalization (Verrecchia 1983; Jovanovic 1982b; Lanen and Verrecchia 1987). Since disclosure quality impacts firms' cost of capital, firms with a higher need for financing have more incentive to increase disclosure quality (Lambert et al. 2007). Beyond financing needs, higher disclosure quality is also associated with lower litigation risk (Francis, Philbrick, and Schipper 1994) and higher investment efficiency (Bushman and Smith 2001, Biddle and Hilary 2006). While there are many benefits for firms to issue higher quality disclosures, managers also have personal costs to provide these disclosures, including personal effort and the ability to extract rents (Anderson et al. 2009). Because of the differing firm strategies and goals at different life cycle stages, management incentives will also differ across life cycle stages.

Introduction firms have a greater need for financing to grow. Pecking order theory states that firms tend to seek bank debt before equity for financing because of tax benefit (Diamond 1991; Barclay and Smith 2005). As the amount of debt increases, the pressure from the anticipation of less liquidity in the future also grows, which leads to underinvestment in positive net present value projects (Barclay and Smith 2005). However, if introduction firms can lower their cost of capital, 
the financing pressure can be partially released because their interest expense will be lower, which also contributes to current cash flow. In fact, Hasan et al. (2015) find that cost of capital is higher for introduction firms. Prior literature has found a negative relationship between cost of capital and disclosure quality (Lambert et al. 2007), so it is highly likely that introduction firms would like to increase their disclosure quality to lower their cost of capital. Our first hypothesis is stated as follows

H1: Disclosure quality of introduction firms is higher than that for shake-out firms.

Growing firms tend to make large early investments to deter entry (Spence 1977, 1979, 1981) and typically have a high growth rate of sales and net operating assets (Dickinson 2011). Again, these are firms in need of financing to meet their investment needs. Dickinson (2011) shows that growth firms have the highest leverage among all life stages. Therefore, lowering the cost of capital is important to growth firms. Lambert et al. (2007) and Francis et al. (2008) find that higher disclosure quality reduces the cost of capital, while Kkhurana et al. (2006) and Bushman and Smith (2003) find a positive relation between disclosure quality and the growth rates of externally financed projects. Additionally, growth firms shift toward greater transparency and increased monitoring (Filatotchev et al. 2006), resulting in higher disclosure quality. Prior research suggests that growth firms have more analyst following (Barth et al. 2001) and are more likely to receive coverage in the business press (Bentley et al. 2017). Thus information asymmetry about growth firms is expected to be lower. Thus, our second hypothesis is stated as follows:

H2: Disclosure quality of growth firms is higher than that for shake-out firms.

Mature firms are more profitable and are more likely to pay dividends and do my repurchases (Dickinson 2011; Grullon and Michaely 2002; and DeAngelo et al. 2006). Since mature firms are already large in size and operate with profit, these firms do not need to make 
large investments and instead begin to pay off previously acquired debt. Thus, mature firms do not have a direct need to lower the cost of capital. However, other aspects of mature firms could serve to increase their disclosure quality. O'Connor and Byrne (2015) provide evidence that firm governance quality is greatest when firms are mature, indicating that information is likely to be disclosed in a timely manner. Moreover, mature firms have the highest average age (Dickinson 2011), and with the longer period present in the capital market, news from the firm should be more readily reflected in the market. Both higher-quality governance and a longer period of operation could result in higher disclosure quality, which corresponds to Hasan et al. (2015) findings that mature firms have a lower cost of capital. Therefore, our third hypothesis is stated as follows:

H3: Disclosure quality of mature firms is higher than that for shake-out firms

Finally, firms in the decline stage have negative profits (Wernerfelt 1985). Following the arguments for introduction firms, the information from decline firms contains more "bad" news than "good" news. Moreover, Jenkins et al. (2004) find that as firms mature, and especially as a firm progresses from the maturity to decline stage, the emphasis on profitability increases. Therefore, it is more likely that the "bad" news might not be disclosed in a timely manner. In addition, firms in the decline stage are actively trying to survive by selling off investments to maintain cash reserves and remove unprofitable assets. The focus is likely on staying relevant in the public eye and continuing the business rather than on providing highly detailed information about the firm. In fact, management would likely prefer to withhold information rather than present it to investors resulting in lower disclosure quality. With this in mind, our fourth hypothesis is stated as follows

H4: Disclosure quality of decline firms is lower than that for shake-out firms. 


\subsection{METHODOLOGY}

\subsection{Life cycle measure}

Anthony and Ramesh (1992) developed a proxy for firm life cycle that considers variables such as sales growth, capital expenditures, dividend payout, and age. By combining the ranks of these four variables, Anthony and Ramesh (1992) divide firms into three life cycle stages: growth, mature, and stagnant. This method assumes a uniform distribution of the firm-observations. However, Dickinson (2011) argues that some performance measures and firm characteristics are nonlinearly related to firm life cycle. Realizing the drawbacks of using firm characteristics to identify firm life cycles, Dickinson (2011) developed a firm life cycle proxy based on cash flows data, which became readily available when the statement of cash flows became a required disclosure after the sample period used in Anthony and Ramesh (1992). Dickinson argues that cash flows' signs capture the differences in firm profitability, growth, and risk. Following Gort and Klepper (1982), Dickinson separates firms into five life cycle stages: (1) introduction, where a firm introduces a new product commercially; (2) growth, where a firm is in an industry where the numbers of producers increase dramatically; (3) mature, where a firm is in an industry where the number of producers and entrants reach a balance; (4) shake-out, where a firm is in an industry where the number of producers begins to decline; and (5) decline, a firm is in an industry where the number of entry is zero. The cash flow proxy results in a distribution of firms that is not significantly different from a normal distribution (Dickinson 2011). Each cash flow can be either positive or negative, resulting in are eight possible combinations of the signs (+/-) of the three cash flows. For example, if a firm has negative cash flows from operating and investing activities and positive cash flows from financing activities, the firm is at the introduction stage. We utilize the 
same methodology as Dickinson (2011) to identify annual firm life cycle stages. A breakdown of the life cycle stages determined by cash flow signs is presented in Figure 2.1.

\section{INSERT FIGURE 2.1}

\subsection{Disclosure measure}

Disclosure quality indicates firm behavior and is associated with trading characteristics and analyst behaviors. Prior studies typically use a combination of disclosure or informationasymmetry-related variables to create a disclosure quality index. For example, Lee et al. (2006) identify higher disclosure quality as having high institutional holdings, low bid-ask spread, and high analyst following and find that firms with poor disclosure quality tend to report comprehensive income in a statement of equity and face high cost of transparency. Anderson et al. (2009) create an opacity index, which includes trading volume, bid-ask spread, analyst following, analyst forecast errors, and finding that both founder and heir firms are significantly opaquer (i.e., of higher disclosure quality) than diffuse shareholder firms. In analyzing firm disclosure practices, Lang and Lundholm (1996) identified three analysts' behavior variables related to better disclosures: analyst forecast dispersion, analyst forecast error, and revision volatility. This is evidence that analyst behaviors are an indicator of disclosure quality. If a firm has high disclosure quality, analysts will have more consensus in their predictions (i.e., lower forecast dispersion), information asymmetry will be lower (i.e., lower forecast error), and new information will be conveyed to analysts in a timely manner (i.e., lower revision volatility). Hui and Mastunaga (2015) utilize these variables to develop a disclosure index to study disclosure quality and CEO compensation. Following Hui and Matsunaga (2015), we rank the three variables by deciles in descending order, add 3 to the sum of the ranking scores, and divide it by 30 . This results in a 
disclosure quality index ranging from 0.1 to 1 , where higher values of the index indicate higher disclosure quality.

\subsection{Regression model}

To obtain management's impact on disclosure quality, we use the following OLS regression model, and this model is referred to as Model (1) in this study:

$$
\begin{aligned}
\text { DiscQual }_{i}=\quad & \beta_{0}+\beta_{1} \text { Size }_{i t}+\beta_{2} \text { MTB }_{i t}+\beta_{3} R O A_{i t}+\beta_{4} R O A_{-} \text {Vol }_{i t}+\beta_{5} \text { Loss }_{i t}+\beta_{6} \text { Analysts }_{i t} \\
& +\beta_{7} \text { Leverage }_{i t}+\beta_{8} R \& D_{i t}+\beta_{9} \text { For_Sales }_{i t}+\beta_{10} \text { LogSeg }_{i t} \\
& +\beta_{11} \text { Shareholdersit }+\beta_{12} \text { ROA } \\
& +\beta_{14} \text { Year Dummies }+\varepsilon_{13} \text { Industry Dummies }
\end{aligned}
$$

\begin{tabular}{|c|c|c|}
\hline DiscQual & $=$ & $\begin{array}{l}\text { Disclosure quality index calculated by ranking the } \\
\text { forecast dispersion, forecast error, and revision volatility } \\
\text { in descending order, adding three to the sum of the ranking } \\
\text { scores, and dividing by } 30 ;\end{array}$ \\
\hline Size & $=$ & Natural log of total assets; \\
\hline$M T B$ & $=$ & Market-to-book ratio of equity; \\
\hline$R O A$ & $=$ & $\begin{array}{l}\text { Earnings before extraordinary items divided by total } \\
\text { assets; }\end{array}$ \\
\hline ROA_Vol & $=$ & $\begin{array}{l}\text { Standard deviation of change in annual return on assets } \\
\text { for the six years immediately before the current year; }\end{array}$ \\
\hline Loss & $=$ & 1 if a firm is suffering loss, 0 otherwise; \\
\hline Analysts & $=$ & Number of analysts following the firm; \\
\hline Leverage & $=$ & Ratio of book value of debt to book value of assets; \\
\hline$R \& D$ & $=$ & $\begin{array}{l}\text { Research and development expenses divided by total } \\
\text { assets; }\end{array}$ \\
\hline For_Sales & $=$ & Foreign sales divided by total assets; \\
\hline $\operatorname{LogSeg}$ & $=$ & Natural log of the number of business segments; and \\
\hline Shareholders & $=$ & Number of common shareholders. \\
\hline
\end{tabular}

Where: 
The dependent variable is the disclosure quality index. Following Hui and Mastunaga (2015), we include in the model the variables that potentially have an impact on disclosure quality. The variables include firm size (Size), market-to-book ratio (MTB), profitability (ROA, Loss), operation stability $\left(R O A \_V o l\right)$, foreign sales (For_Sales), R\&D intensity $(R \& D)$, total number of common shareholders and number of segments (LogSeg). Hui and Mastunaga (2015) expect that firm profitability, operation stability, and operation complexity are likely to impact disclosure quality. We also include Industry Dummies and Year Dummies controls for the industry effect and time effect on disclosure quality, respectively. Standard errors are clustered at firm level.

According to Hui and Mastunaga (2015), the residuals of this model are the proportion of disclosure quality that cannot be explained by these fundamental variables and thus indicate management's impact on disclosure quality. Therefore, we compare disclosure quality residuals across life cycle stages as our main analysis.

\subsection{SAMPLES AND EMPIRICAL RESULTS}

\subsection{Samples}

The sample is drawn from the WRDS database. Compustat contains financial information, which is the source of the fundamental variables that impacts disclosure quality, while the analyst forecast data comes from I/B/E/S. Since firm life cycle stage is defined using the signs of cash flows (Dickinson 2011), we extract our sample from the year beginning in 1988, which is the year that cash flow statement data first became available as mandated by FASB Statement No. 95 (FAS 95). As for the fundamental variables, $R O A$ is the earnings from the current year divided by previous year's total assets, and $\mathrm{ROA}_{-} \mathrm{Vol}$ is the rolling standard deviation of change in annual ROA for the six years immediately before the current year. For the variables For_Sales and $R \& D$, Foreign sales and R\&D expenses are both adjusted by the prior year's total assets, respectively. 
Thus, the first six years of observations for each firm are deleted, and the final sample period begins with the year 1993.This leaves us with 129,475 observations from the Compustat database for fundamental data. In terms of the I/B/E/S analyst data, following (Long and Lundhulm 1996), we use the end of year standard deviation adjusted by the beginning-of-year stock price. The endof-year record also represents the number of analysts. The forecast error in the disclosure quality index is measured as the absolute value of the difference between the actual EPS and the mean estimates, divided by the previous year's closing price. The total I/B/E/S samples then leave us with 117,067 observations. After merging the Compustat database and I/B/E/S database, we have a final sample of 45,245 observations in this study. The sample selection procedure is shown in Panel A of Table 2.1.

Panel B of Table 2.1 shows summary statistics of disclosure quality variables and fundamental variables on the overall sample. The summary statistics by firm life cycle stage are reported in Table 2.2. The proportion of firms in each life cycle corresponds with Dickinson (2011), with the largest proportions of firms at the growth (30.79\%) and mature (43.18\%) stages, and the lowest proportion in decline (6.78\%) firms. Dickinson (2011) does not find a significant difference in the Market-to-Book ratio between firm life cycles. However, our sample shows that growth firms have the highest average Market-to-Book ratio (5.802), which possibly represents the higher market expectation of firm growth. A higher Market-to-Book ratio is also found in decline firms, which possibly indicates that these firms are over-valued. We also observe that mature firms have the highest disclosure quality (0.578), while decline firms bear the lowest (0.523) quality.

INSERT TABLE 2.1

INSERT TABLE 2.2 


\subsection{Empirical results}

\subsubsection{Main results}

Table 2.3 presents the correlation matrix for the variables included in our regression model. We observe that the Pearson correlation coefficients between DisQual and the control variables are significant for Size, ROA, Leverage, For_Sales, $R \& D$, and LogSeg. The significance of these control variables validates their inclusion in the regression model. As such, we turn to our multivariate analysis.

\section{INSERT TABLE 2.3}

\section{INSERT TABLE 2.4}

The results of our OLS regression model (Equation 1) are shown in Table 2.4. In the table, we find that size, leverage, loss indicator, $R \& D$ are negatively associated with disclosure quality, and foreign sales and total number of segments are positively associated with disclosure quality. Total number of observations in the regression model is 37,453 , because the model include a leading ROA and more observations are dropped because of lack of data.

We obtain residuals from Model (1) as our measure of disclosure quality that is impacted by the management and see if the disclosure quality residuals are different across firm life cycle stages. The average disclosure quality residuals are shown in Table 2.5. From the table, we can see that the average residuals are positive for growth and mature firms, while negative for introduction, shake-out and decline firms. This provides evidence that growth firms and mature firms have higher disclosure quality, followed by introduction firm, and shake-out firms and decline firms have lower disclosure quality, as is impacted by the management efforts.

\subsubsection{Additional analysis}


We also track if the trend of management's impact on disclosure changes across firm life cycle stages. We provide how residuals of disclosure quality changes at $t+1$, and $t+2$ years after the first year firm life cycle is identified. The trend is shown in Table 2.5. The disclosure residuals for introduction and decline firms decrease over time, while those for growth and mature firms increase over time. Even though shake-out firm has negative disclosure quality residuals, the absolute value of disclosure quality residuals decreases over time. This indicates that the disclosure quality residuals for shake-out firms increase over time.

\section{INSERT TABLE 2.5}

\subsection{CONCLUSION}

Given that disclosures are a primary form of communication between firms and investors, disclosures' quality is essential. In particular, higher disclosure quality leads to lower information asymmetry, thus making capital markets more efficient (Brown and Hillegeist 2007). In this paper, we examine the effect of firms' life cycle stage on disclosure quality. Prior literature documents that firms' incentives and subsequent behavior differ depending on their current life cycle stage, and, as such, it is possible that life cycle stages influence the quality of firms' disclosures. Overall, we find that disclosure quality differs across firm life cycles. Specifically, firms currently included in the growth, and mature life cycle stages have higher disclosure quality than firms in other stages, suggesting that life cycle stages impact disclosure quality.

Our study contributes to the literature examining financial disclosures by documenting firm life cycles as a significant determinant of disclosure quality. Prior study finds that disclosure quality is negatively associated with cost of capital. Research that studies firm life cycle and cost of capital also finds that growth and mature firms have lower cost of capital than other firm groups. Our results correspond to these relationships and find that disclosure quality is higher for growth 
and mature firms than other firm groups. Lastly, since analysts' and investors' behaviors are associated with disclosure quality, identifying firm life cycle is associated with disclosure quality, our results will help financial report users make better decisions. 


\section{References}

Anderson, R.C., Duru, A. and Reeb, D.M. 2009. Founders, heirs, and corporate opacity in the United States. Journal of Financial economics 92 (2): 205-222.

Anthony, J.H. and Ramesh, K. 1992. Association between accounting performance measures and stock prices: A test of the life cycle hypothesis. Journal of Accounting and economics 15(23): 203-227.

Banyi, M.L. and Kahle, K.M. 2014. Declining propensity to pay? A re-examination of the lifecycle theory. Journal of Corporate Finance 27: 345-366.

Barclay, M.J. and Smith, C.W. 2005. The capital structure puzzle: The evidence revisited. Journal of Applied Corporate Finance 17 (1): 8-17.

Barron, O.E. and Qu, H. 2014. Information asymmetry and the ex ante impact of public disclosure quality on price efficiency and the cost of capital: Evidence from a laboratory market. The Accounting Review 89 (4): 1269-1297.

Barth, M.E., Kasznik, R. and McNichols, M.F. 2001. Analyst coverage and intangible assets. Journal of accounting research 39 (1): 1-34.

Biddle, G.C. and Hilary, G. 2006. Accounting quality and firm-level capital investment. The Accounting Review 81 (5): 963-982.

Botosan, C.A. 1997. Disclosure level and the cost of equity capital. Accounting review: 323-349.

Botosan, C.A. and Plumlee, M.A. 2002. A re-examination of disclosure level and the expected cost of equity capital. Journal of accounting research 40 (1): 21-40.

Brown, S. and Hillegeist, S.A. 2007. How disclosure quality affects the level of information asymmetry. Review of Accounting Studies 12 (2-3): 443-477.

Bushman, R.M. and Smith, A.J. 2001. Financial accounting information and corporate governance. Journal of accounting and Economics 32(1-3): 237-333.

Choi, J., Choi, W. and Lee, E., 2016. Corporate life cycle and earnings benchmarks. Australian Accounting Review 26(4): 415-428. 
DeAngelo, H., DeAngelo, L. and Stulz, R.M. 2006. Dividend policy and the earned/contributed capital mix: a test of the life-cycle theory. Journal of Financial economics 81 (2): 227-254.

Diamond, D.W. 1991. Monitoring and reputation: The choice between bank loans and directly placed debt. Journal of political Economy 99 (4): 689-721.

Dickinson, V. 2011. Cash flow patterns as a proxy for firm life cycle. The Accounting Review 86 (6): 1969-1994.

Drake, M.S., Myers, J.N. and Myers, L.A. 2009. Disclosure quality and the mispricing of accruals and cash flow. Journal of Accounting, Auditing \& Finance 24(3): 357-384.

Easley, D. and O'hara, M. 2004. Information and the cost of capital. The journal of finance 59 (4): 1553-1583.

Faff, R., Kwok, W.C., Podolski, E.J. and Wong, G. 2016. Do corporate policies follow a lifecycle? Journal of Banking \& Finance 69: 95-107.

Filatotchev, I., Toms, S. and Wright, M. 2006. The firm's strategic dynamics and corporate governance life-cycle. International Journal of Managerial Finance 2 (4): 256-279.

Francis, J., Nanda, D. and Olsson, P. 2008. Voluntary disclosure, earnings quality, and cost of capital. Journal of accounting research 46 (1): 53-99.

Francis, J., Philbrick, D. and Schipper, K., 1994. Shareholder litigation and corporate disclosures. Journal of accounting research 32(2): 137-164.

Gao, P. 2010. Disclosure quality, cost of capital, and investor welfare. The Accounting Review 85 (1): 1-29.

Gietzmann, M. and Ireland, J. 2005. Cost of capital, strategic disclosures and accounting choice. Journal of Business Finance \& Accounting 32 (3-4): 599-634.

Gort, M. and Klepper, S. 1982. Time paths in the diffusion of product innovations. The economic journal 92 (367): 630-653.

Grullon, G. and Michaely, R., 2002. Dividends, share repurchases, and the substitution hypothesis. the Journal of Finance, 57(4), pp.1649-1684. 
Habib, A. and Hasan, M.M. 2017. Firm life cycle, corporate risk-taking and investor sentiment. Accounting \& Finance 57 (2): 465-497.

Hasan, M.M., Hossain, M. and Habib, A. 2015. Corporate life cycle and cost of equity capital. Journal of Contemporary Accounting \& Economics 11 (1): 46-60.

Hasan, M.M., Al-Hadi, A., Taylor, G. and Richardson, G. 2017. Does a firm's life cycle explain its propensity to engage in corporate tax avoidance? European Accounting Review 26 (3): 469-501.

Healy, P.M., Hutton, A.P. and Palepu, K.G. 1999. Stock performance and intermediation changes surrounding sustained increases in disclosure. Contemporary accounting research 16 (3): 485-520.

Healy, P.M. and Palepu, K.G. 2001. Information asymmetry, corporate disclosure, and the capital markets: A review of the empirical disclosure literature. Journal of accounting and economics 31 (1-3): 405-440.

Hribar, P. and Yehuda, N. 2015. The mispricing of cash flows and accruals at different life-cycle stages. Contemporary Accounting Research 32 (3): 1053-1072.

Hui, K.W. and Matsunaga, S.R. 2015. Are CEOs and CFOs rewarded for disclosure quality? The Accounting Review 90 (3): 1013-1047.

Jenkins, D.S., Kane, G.D. and Velury, U. 2004. The impact of the corporate life-cycle on the valuerelevance of disaggregated earnings components. Review of Accounting and Finance 3 (4): $5-20$.

Jovanovic, B. 1982b. Truthful disclosure of information. The Bell Journal of Economics: 36-44.

Khurana, I.K., Pereira, R. and Martin, X. 2006. Firm growth and disclosure: An empirical analysis. Journal of Financial and Quantitative Analysis 41 (2): 357-380.

Lambert, R., Leuz, C. and Verrecchia, R.E. 2007. Accounting information, disclosure, and the cost of capital. Journal of accounting research 45 (2): 385-420.

Lanen, W.N. and Verrecchia, R.E. 1987. Operating decisions and the disclosure of management accounting information. Journal of Accounting Research 165-189. 
Lang, M.H. and Lundholm, R.J. 1996. Corporate disclosure policy and analyst behavior. The Accounting review: 467-492.

Lee, Y.J., Petroni, K.R. and Shen, M. 2006. Cherry picking, disclosure quality, and comprehensive income reporting choices: The case of property-liability insurers. Contemporary Accounting Research 23(3): 655-692.

Leuz, C. and Verrecchia, R.E. 2000. The economic consequences of increased disclosure. Journal of accounting research: 91-124.

Myers, S.C. 1977. Determinants of corporate borrowing. Journal of financial economics 5 (2): 147-175.

O'Connor, T. and Byrne, J. 2015. Governance and the corporate life-cycle. International Journal of Managerial Finance 11 (1): 23-43.

Spence, A.M. 1977. Entry, capacity, investment and oligopolistic pricing. The Bell Journal of Economics: 534-544.

Spence, A.M. 1979. Investment strategy and growth in a new market. J. Reprints Antitrust L. \& Econ. 10: 345.

Spence, A.M. 1981. The learning curve and competition. The Bell Journal of Economics: 49-70.

Suberi, A. Z. M., Hsu, G., \& Wyatt, A. 2012. The relation between firm growth and accounting quality: A test of the life cycle hypothesis, Working Paper, University of Queensland, Australia.

Verrecchia, R.E. 1983. Discretionary disclosure. Journal of accounting and economics 5: 179-194.

Verrecchia, R.E., 2001. Essays on disclosure. Journal of accounting and economics, 32(1-3), pp.97-180.

Welker, M. 1995. Disclosure policy, information asymmetry, and liquidity in equity markets. Contemporary accounting research 11 (2): 801-827.

Wernerfelt, B. 1985. The dynamics of prices and market shares over the product life cycle. Management Science 31 (8): 928-939. 
Figure 2.1 Firm life cycle stages according to the signs of cash flows

$\begin{array}{lcccccc} & 1 & 2 & 3 & 4 & 5 & 6 \\ & \text { Introduction } & \text { Growth } & \text { Mature } & \text { Shake-Out } & \text { Shake-Out } & \text { Decline } \\ \begin{array}{c}\text { Cash flow from } \\ \text { operating activities }\end{array} & - & + & + & - & + & - \\ \begin{array}{c}\text { Cash flow from } \\ \text { investing activities }\end{array} & - & - & - & - & + & + \\ \begin{array}{c}\text { Cash flow from } \\ \text { financing activities }\end{array} & + & + & - & - & +/- & +/-\end{array}$

Source: Dickinson (2011)

Dickinson (2011) assigns firm life cycle stages according to the signs of cash flows. For example, if a firm has negative cash flows from operating activities and investing activities, but positive cash flows from financing activities, then the firm is at introduction stage. This firm life cycle stage is non-linear, which means that the life cycle stages do not follow a sequential pattern. For example, Coca-Cola company was at mature stage from the year 1990 to the year 2007, but it was at growth stage in 2008, and CVS company went from decline stage to growth stage from 1997 to 1998. 
Table 2.1 Sample Selection and Description

Panel A: Sample Selection Procedure (1993-2018)

Fundamental data from Compustat

I/B/E/S data available

Total number of observations
Number of Firm-years

129,457

117,067

45,245
Number of firms

16,573

16,213

6,403

Panel B: Distribution Statistics $(n=45,245)$

\begin{tabular}{|c|c|c|c|c|c|}
\hline & Mean & Std. Dev. & Q1 & Median & Q3 \\
\hline DQ Index & 0.560 & 0.178 & 0.433 & 0.567 & 0.700 \\
\hline Log_Assets & 6.942 & 1.917 & 5.583 & 6.836 & 8.166 \\
\hline MB Ratio & 4.091 & 219.916 & 1.292 & 2.151 & 3.696 \\
\hline ROA & -0.016 & 0.433 & -0.020 & 0.035 & 0.082 \\
\hline ROA Volatility & 5.671 & 179.295 & 0.025 & 0.057 & 0.144 \\
\hline Loss & 0.305 & 0.460 & 0.000 & 0.000 & 1.000 \\
\hline Analysts & 8.241 & 6.791 & 3.000 & 6.000 & 11.000 \\
\hline Leverage & 0.223 & 0.243 & 0.012 & 0.171 & 0.348 \\
\hline$R \& D$ & 0.064 & 0.165 & 0.000 & 0.000 & 0.069 \\
\hline Foreign Sales & 0.012 & 0.059 & 0.000 & 0.000 & 0.013 \\
\hline Shareholders & 36.293 & 2383.892 & 0.205 & 1.095 & 6.200 \\
\hline Segments & 1.185 & 0.710 & 0.693 & 0.693 & 1.386 \\
\hline
\end{tabular}


Table 2.2 Descripted Statistics by Life Cycle Stage

\begin{tabular}{|c|c|c|c|c|c|c|}
\hline & Pooled & Introduction & Growth & Mature & Shake-out & Decline \\
\hline $\mathrm{n}$ & 45,245 & 4,373 & 13,933 & 19,335 & 4,338 & 3,066 \\
\hline$\%$ of $n$ & $100 \%$ & $9.67 \%$ & $30.79 \%$ & $43.18 \%$ & $9.59 \%$ & $6.78 \%$ \\
\hline DQ Index & 0.556 & 0.534 & 0.560 & 0.578 & 0.525 & 0.523 \\
\hline Log Assets & 6.942 & 5.420 & 7.124 & 7.426 & 7.6.940 & 5.198 \\
\hline MB Ratio & 4.091 & 0.834 & 6.188 & 3.444 & 2.888 & 5.031 \\
\hline ROA & -0.016 & -0.359 & 0.042 & 0.061 & 0.020 & -0.327 \\
\hline ROA Volatility & 5.671 & 17.976 & 4.881 & 2.728 & 4.978 & 11.441 \\
\hline Loss & 0.305 & 0.812 & 0.218 & 0.153 & 0.362 & 0.867 \\
\hline Analysts & 8.241 & 5.621 & 8.434 & 9.380 & 4.723 & 5.007 \\
\hline Leverage & 0.222 & 0.213 & 0.245 & 0.220 & 0.204 & 0.179 \\
\hline For_Sales & 0.012 & -0.013 & 0.013 & 0.020 & 0.009 & -0.009 \\
\hline$R \& D$ & 0.064 & 0.223 & 0.043 & 0.024 & 0.054 & 0.202 \\
\hline Segments & 1.185 & 1.034 & 1.192 & 1.228 & 1.212 & 1.048 \\
\hline
\end{tabular}

a. Disclosure index (dependent variable) 
Table 2.3 Correlation coefficients between Disclosure quality (DiscQual) and the independent variables

\begin{tabular}{|c|c|c|c|c|c|c|c|c|c|}
\hline & DiscQual & Size & ROA & MTB & Leverage & $\begin{array}{c}\text { ROA_ } \\
\text { Vol }\end{array}$ & $\begin{array}{l}\text { For_ } \\
\text { Sales }\end{array}$ & R\&D & LogSeg \\
\hline DQ Index & & -0.0244 & 0.2214 & 0.3108 & -0.1160 & -0.1299 & 0.1557 & 0.0922 & 0.0335 \\
\hline Size & -0.0362 & & 0.2305 & $\mathbf{- 0 . 0 3 9 7}$ & 0.3818 & -0.5229 & 0.2127 & -0.3652 & 0.1591 \\
\hline $\mathrm{ROA}$ & 0.0603 & 0.2037 & & 0.3153 & $-\mathbf{0 . 0 8 9 7}$ & -0.2821 & 0.3331 & -0.1918 & 0.0395 \\
\hline МТВ & 0.0032 & 0.0060 & 0.0089 & & -0.1060 & 0.0542 & 0.1401 & 0.2437 & 0.0337 \\
\hline Leverage & -0.1124 & 0.2102 & -0.0385 & 0.0073 & & -0.2156 & -0.0244 & -0.3200 & 0.0154 \\
\hline ROA_Vol & -0.0057 & 0.0070 & -0.0067 & 0.0031 & 0.0035 & & -0.1895 & 0.4155 & -0.0751 \\
\hline For_Sales & 0.0875 & 0.1326 & 0.1959 & 0.0004 & -0.0439 & -0.0024 & & 0.0973 & 0.0524 \\
\hline $\mathrm{R} \& \mathrm{D}$ & 0.0213 & -0.3392 & -0.4925 & -0.0034 & -0.1112 & 0.0035 & -0.0899 & & 0.0308 \\
\hline Logseg & 0.0243 & 0.2047 & 0.0421 & 0.0084 & 0.0039 & -0.0050 & 0.0342 & -0.0538 & \\
\hline
\end{tabular}

This table shows the distributions and correlations for the variables used in the analysis. The numbers below the diagonal

are the Pearson correlation coefficients, and numbers above the diagonal are Spearman correlations. Bold figures are statistically

significant from 0 at the $5 \%$ (two-tailed) level. 
Table 2.4 Regression of Disclosure Quality for Residuals

\begin{tabular}{|c|c|}
\hline VARIABLES & DQ \\
\hline \multirow[t]{2}{*}{ Log_Assets } & $-0.011 * * *$ \\
\hline & $(-7.731)$ \\
\hline \multirow[t]{2}{*}{ MB Ratio } & $0.000 * * *$ \\
\hline & (3.589) \\
\hline \multirow[t]{2}{*}{ ROA } & 0.001 \\
\hline & $(0.294)$ \\
\hline \multirow[t]{2}{*}{ Leverage } & $-0.044 * * *$ \\
\hline & $(-5.928)$ \\
\hline \multirow[t]{2}{*}{ ROA Volatility } & -0.000 \\
\hline & $(-1.147)$ \\
\hline \multirow[t]{2}{*}{ Loss } & $-0.025 * * *$ \\
\hline & $(-7.283)$ \\
\hline \multirow[t]{2}{*}{ Analysts } & $0.006 * * *$ \\
\hline & (19.968) \\
\hline \multirow[t]{2}{*}{$\mathrm{R} \& \mathrm{D}$} & $-0.021^{*}$ \\
\hline & $(-1.914)$ \\
\hline \multirow[t]{2}{*}{ Foreign Sales } & $0.083 * * *$ \\
\hline & (3.578) \\
\hline \multirow[t]{2}{*}{ Shareholders } & $-0.000 * * *$ \\
\hline & $(-2.960)$ \\
\hline \multirow[t]{2}{*}{ Segments } & $0.007 * * *$ \\
\hline & $(2.913)$ \\
\hline \multirow[t]{2}{*}{ Leading ROA } & $0.031 * * *$ \\
\hline & (3.656) \\
\hline \multirow[t]{2}{*}{ Constant } & $0.669^{* * * *}$ \\
\hline & (14.106) \\
\hline Observations & $37,453^{2}$ \\
\hline Adjusted R-squared & 0.248 \\
\hline Industry FE & YES \\
\hline Year FE & YES \\
\hline
\end{tabular}

${ }^{2}$ The model includes a leading ROA, which is ROA of the year $t+1$. Therefore, about 1,000 observations are lost. 
Table 2.5 Disclosure Residuals on Life Cycle

\begin{tabular}{|c|c|c|c|c|c|c|}
\hline & Pooled & Introduction & Growth & Mature & Shake-out & Decline \\
\hline \multicolumn{7}{|c|}{$\underline{\text { Year relative to formation }}$} \\
\hline $\mathrm{t}$ & 0.0059 & -0.0022 & 0.0014 & 0.0059 & -0.0221 & -0.0150 \\
\hline $\mathrm{t}+1$ & 0.0058 & -0.0076 & 0.0022 & 0.0118 & -0.0148 & -0.0176 \\
\hline $\mathrm{t}+2$ & 0.0038 & -0.0185 & 0.0030 & 0.0115 & -0.0122 & -0.0207 \\
\hline $\mathrm{N}$ & 45,245 & 4,373 & 13,933 & 19,335 & 4,338 & 3,066 \\
\hline$\%$ of total $n$ & $100 \%$ & $9.67 \%$ & $30.79 \%$ & $43.18 \%$ & $9.59 \%$ & $6.78 \%$ \\
\hline
\end{tabular}




\title{
CHAPTER THREE: FIRM LIFE CYCLE AND FRAUD
}

\author{
Richard A. Riley, Jr \\ John Chambers College of Business and Economics \\ West Virginia University \\ Richard.riley@mail.wvu.edu
}

Trevor L. Sorensen

John Chambers College of Business and Economics

West Virginia University

trevor.sorensen@mail.wvu.edu

\begin{abstract}
Chen Zhao
John Chambers College of Business and Economics

West Virginia University

chzhao@mix.wvu.edu
\end{abstract}

We express our thanks for valuable feedback provided by conference participants at the AAA Mid-Atlantic Region Meeting Doctoral Consortium. 


\begin{abstract}
This study investigates whether firm life cycle is associated with fraud. According to the fraud triangle theory, incentives and opportunities are important factors that lead to fraud (Dorminey, Fleming, Kranacher, and Riley 2012). Following Dickinson (2011), this paper uses cash flow patterns as a proxy for life cycle stages. Firms in different life cycle stages have different combinations of signs of cash flows, so the incentives and opportunities are likely to be different. Therefore, we expect that the likelihood of committing fraud is different across life cycle stages. We identify 182 fraud firms with available data from the AAER database and utilize a 4-to-1 matched sample, as well as the overall sample in our analysis. We find that the introduction firms are more likely to commit fraud, while mature firms are less likely to commit fraud.
\end{abstract}




\subsection{Introduction}

Financial Fraud has been costly for both the business world and society as a whole. Prior research has been studying how to detect fraud from the characteristics of the firms, including the relationship between financial fraud and corporate governance, the pressure to meet analysts' forecasts, and executive compensation (Hogan, Rezaee, Riley and Velury 2008; Bell and Carcello 2000; Dechow, Sloan and Sweeney 1996; and Farber 2005). However, no prior research has studied how firm life cycle stages can impact the likelihood of a firm committing fraud. Firms at different life cycle stages have different goals and incentives, and as a result, the likelihood that a firm commits fraud may be different across life cycle stages. If firm life cycle stages are associated with the likelihood of fraud, financial statement users may be better able to detect fraud. Therefore, this paper aims to identify which life cycle stage firms are more likely to commit fraud.

The study of firm life cycle stages' impact on fraud has two advantages. First, this study investigates the likelihood of fraud from a macro perspective. Prior studies explore the potentially associated variables with fraud from a micro perspective, focusing on individual characteristics of firms or individuals that could lead to fraud. However, cash flow patterns as a proxy for firm life cycle stages imply combinations of different firm characteristics. Both Anthony and Ramesh (1992) and Dickinson (2011) find evidence that firm characteristics are different among life cycle stages, so that firm cycle stages can be considered as "organic" combinations of variables. Therefore, the first advantage of this paper is to study how combinations of naturally formed firm characteristics are associated with fraud, instead of the study of any individual variable. Second, using cash flow patterns

as firm life cycle stage proxy is a costless and parsimonious approach. Cash flow 
information is available on the Statement of Cash Flows of public firms and should be available to auditors if the firm is a private firm, so investors, creditors, and auditors can have easy access to this information. Dickinson derived firm life cycle stages from combinations of the signs of cash flows (see Figure 3.1), and anyone who has access to the signs of cash flows can put the signs in the right bucket and identify firm life cycle stage of the firm year immediately. Therefore, firm life cycle stage is a costless and parsimonious approach. If life cycle stage is associated with the likelihood of fraud, the introduction of this variable into the analysis will be effective and economically efficient.

The sample in this paper is composed of 182 fraud firms identified from the SEC AAER database. Each fraud firm is matched with four non-fraud firms based on industry and total assets in the first year of fraud. The results provide evidence that the likelihood of firms committing fraud is different across life cycle stages. Specifically, introduction firms are most likely to commit fraud, followed by growth and declining firms, while mature firms and shake-out firms are the least likely to commit fraud. Further analysis will include incentives and opportunities variables and how incentives and opportunities interact with life cycle stages in impacting the likelihood of fraud. We carry out a robustness check by including all firm years available and find similar results.

The findings of this paper add to the fraud literature by identifying additional characteristics of firms that are likely to commit fraud. As is mentioned above, this is a costless and parsimonious approach and will help auditors and investors detect or predict fraud more efficiently. It also adds to firm life cycle literature by providing evidence that firm life cycle stages derived from cash flow patterns are associated with additional firm characteristics, i.e., the likelihood of committing fraud. Lastly, this paper provides 
investors, creditors, and auditors with additional information to detect and predict fraud more effectively and efficiently.

\subsection{Background}

Firm life cycle theory suggests that firms transition between different life cycle stages, and the current life cycle stage is determined by various internal and external factors, such as strategy choices, managerial ability, and competitive environment (Dickinson 2011). Prior research has found that firm behaviors are different across life cycle stages. For example, Faff et al. (2016) find that firms make fewer investments and issue less equity as they become more mature, while debt issuance and cash holding decrease as firms enter mature and declining stages. Choi, Choi, and Lee (2016) also find that corporate life cycle plays a significant role in a firm's meeting or beating earnings benchmark behavior. Moreover, as indicated by fluctuation of return on investment and return on equity, corporate risk-taking is higher during the introduction and decline stages, but lower during the mature stage (Habib and Hasan 2017). Other research finds that firm life cycle influences the firms' strategic behaviors. For example, Elsayed and Paton (2009) find that the relationship between financial performance and corporate social responsibility (CSR) engagement varies across life cycle stages. Liu (2006) finds that the differences in operating decisions among life cycles affect accrual qualities.

Research also finds that other firm characteristics are different across firm life cycle stages. Drake and Martin (2015) find that executive compensation is more sensitive to accounting measures in the mature stage. Investors behavior is also found to be different across life cycle stages, as is found by Dickinson, kassa, and Schaber (2018) that investors tend to rely more on analysts' forecasts for growth and mature stages, while accounting 
information is more value-relevant for introduction and decline stages firms. Cost of capital also follows a U-shaped trend with introduction and declining stages have higher cost of capital, while growth and mature stages have lower cost of capital (Hasan et al. 2015). Haribar and Yehuda (2015) find that total accruals and free cash flows are mispriced to various degrees at different life cycle stages. However, no prior research has studied whether firm life cycle stages are associated with the likelihood of fraud.

Dickinson (2011) identifies life cycle stages using a combination directional cash flows from operating, financing, and investing activities (see Figure 3.1), which reflect firm activities. For example, introduction firms have negative cash flows from operating activities, positive cash flows from financing activities, and negative cash flows from investing activities. This implies that introduction firms invest in long-term assets, such as property, plant, and equipment, using external financing. Similar implications apply to other firm life cycle stages as well. Dickinson (2011) also provides evidence that firm characteristics, such as size, profitability, and operating efficiency, are different across life cycle stages. An advantage of the cash flow proxy to define life cycle stages is that it defines life cycle stages based on an "organic" combination of firm activities and characteristics, and the life cycle stages do not transition monotonically. Given that firms are continually developing new products, Dickinson (2011) argues that a firm should be considered a portfolio with different products at different life cycle stages. Therefore, firm life cycle stages are not monotone like firm age. An old firm can be in the introduction stage if it focuses on a new product. The firm might need to invest in new equipment and might also need to finance the investment. In addition, because the firm is trying to introduce the new product, it might have lenient receivable collecting policies and have 
negative cash flows from operating activities. In this way, the signs of cash flows fit in the bucket of introduction firm and the old firm come to be at introduction stage. Similar analysis applies to other age and life cycle stage combinations as well.

\section{INSERT FIGURE 3.1}

Prior research has explored the possible associations between firms' or employees' specific activities and fraud to help auditors increase the likelihood of detecting fraud. For example, Clor-Proell, Kaplan, and Proell (2015) find that budget goal difficulty and promotion availability interact in affecting the employees' behavior. Other research also finds the association between affiliations and fraud (Perri and Brody 2012). In a field study, Carpenter (2007) finds evidence that brainstorming helps audit teams generate new quality fraud ideas and improve fraud risk assessments. Wilks and Zimbelman (2004) also propose using game theory and strategic reasoning concepts to prevent and detect fraud. Some other research finds the association between firm characteristics and fraud. For example, research finds that executive compensation, the board of directors' composition, and corporate governance are found to be associated with fraud, and that abnormal turnover of outside directors is related to financial fraud (Erickson, Hanlon, and Maydew 2006; Burns and Kedia 2006; Beasley 1996; Collins, Gong, and Li 2009; and Gao, Kim, Tsang, and Wu 2017). However, no prior research has studied whether firm life cycle stage is related to the likelihood of fraud.

According to the fraud triangle, three criteria must be present for fraud to occur: perceived pressure, perceived opportunity, and rationalization (Dorminey, Fleming, Kranacher and Riley 2012; Trompeter, Carpenter, Desai, Jones, and Riley 2013). As is discussed above, strategy choices and competitive environment are different across firm 
life cycle stages. Therefore, it is likely that the firm incentives are various across life cycle stages. For example, introduction and growth firms rely on financing to fund operation and investment, so these firms have more substantial incentives to improve their financial reports to lower cost of capital, while mature firms do not have these incentives. If financing and operating are the main focus of the management, corporate governance will likely be weaker. Therefore, this paper focuses on different incentives and opportunities and how these incentives and opportunities interact with life cycle stages to impact the likelihood of fraud. Rationalization is not included in this analysis because we are unaware of an archival method that can assess rationalization.

Empirically, research has provided evidence that CEOs have incentives to meet earnings expectations (Payne and Robb 2000; Matsunaga and Park 2001; and Boschen, Duru, Gordon and Smith 2003). Graham, Harvey, and Rajgopal (2005) suggest that CFOs also tend to beat earnings benchmarks and seek to commit earnings smoothing. Hogan et al. (2008) also discussed the characteristics of firms committing financial statement fraud as identified in the literature, and they find that firms that are pressured to meet analysts' forecasts, rapid growth (Bell and Carcello 2000), the need for financing, and poor performance (Dechow et al. 1996) are more likely to commit financial reporting fraud. Introduction firms and growth firms have positive cash flows from financing activities, which indicates that these firms acquire funds to expand and grow. Therefore, introduction and growth firms have more substantial incentives to lower cost of capital than mature firms, which do not acquire financing to fund other activities. Operating cash flows are positive in growth firms but negative in introduction firms. This difference implies that even though they have the same incentives to acquire more financing, introduction firms 
are under more severe financial pressure than growth firms do. Other differences in incentives are also likely to be generated from the different combinations of cash flows. Therefore, the likelihood of fraud is different across life cycle stages. Besides, the above analysis also suggests that introduction and growth firms have more substantial incentives to commit fraud, while the incentives for introduction firms are more substantial because they face more severe financial pressure.

Opportunity is the perception that the control is weak and that the chance of being caught of committing the fraud is slight. Opportunities are significant for fraud behavior to exist. A perpetrator (a firm or individual) cannot carry out the fraudulent behavior if there are no opportunities, even though incentives exist. Corporate governance is strongly associated with the likelihood of financial fraud (Dechow et al. 1996; Beasley 1996; Beasley Carcello, Hermanson and Lapides 2000; and Farber 2005). Collins, Gong, and Li (2009) find that corporate governance is associated with the backdating of executive stock options, and Bell and Carcello (2009) find that weak internal control is related to the incidence of fraud. Prior research has also found that the board of director composition, related party transactions are associated with financial statement fraud (Beasley 1996; Gordon, Henry, Louwers and Reed 2007). If managers of firms at certain life cycle stages have to put most of their effort into operation and financing, corporate governance is likely to be weakened. Therefore, we expect the opportunities of fraud to be different across firm life cycle stages, which may impact the firms' likelihood of committing fraud.

Prior research addressed that firm or industry growth stages impact the likelihood to commit fraud. The National Commission on Fraudulent Financial Reporting (American Institute for Certified Public Accountants, 1987: 29) suggests that newly public companies 
are more likely to commit financial statement fraud. Research has also found that when the industry is growing fast, the likelihood of managerial fraud increases, and that in declining industries, the incidence of management fraud is likely to be higher (Hansen et al. 1996). However, no research has captured whether and how the specific firm life cycle stage is associated with the likelihood of fraud, and there were no explicitly defined firm life cycle

proxies in that research. Using cash flows as a proxy for firm life cycle, following Dickinson (2011), this paper studies the likelihood of fraud across firm life cycle stages.

\subsection{Hypotheses development}

Different firm life cycle stages have different cash flow patterns, and the combinations of the signs of cash flows reflect the firm's current financial situation. The combinations of cash flow activities highlight some potential incentives for committing fraud. According to expectation theory and prospect theory, people make decisions by considering both the potential gain and the losses of the options. This applies to management fraudulent behavior. Management can smooth earnings or have personal financial gains if they commit misreporting or asset misappropriation. However, they are at risk of being caught, face legal action, reputational costs, and difficulty obtaining financing in the future. For example, earnings manipulation can lower cost and capital, but cost of capital will be higher if the fraudulent behavior is detected (Dechow, Sloan, and Sweeney 1996). Intuitively, the losses will be more significant for firms generating cash inflows from day-to-day business than for those that are not. Therefore, we use the firm life cycle approach to evaluate how a firm situation from a general picture impacts the likelihood of fraud. 
Even though our analysis is based on firm life cycles, it is essential to understand the impact of each section of cash flows on the incentives and opportunities for committing fraud. Negative cash flow from operating activities is an indicator that the company is struggling to generate cash inflows from the business's day-to-day operations, even when reporting a profit on the income statement. Because negative cash flows from operating activities can be somewhat concerning to investors, managers have an increased incentive to commit fraud to make things appear better. The PCAOB AS §2401.85 illustrates the examples of fraud incentives and opportunities, and financial pressure is among the most important incentives for firms to commit fraud. As a result, the firm life cycle stages with negative cash flow from operating activities (i.e., the introduction and decline stages) might be more likely to commit fraud due to increased financial pressure.

Financing activities might also cause incentives for fraud. Pecking order theory suggests that firms access bank debts first then issue stocks (Myers 1984; Diamond 1991). Firms that need financing have to keep decent financial performance to obtain funding from creditors or investors. When firms' performance deteriorates, there are more substantial incentives to make financial performance look better through fraudulent means. While other firms might also have incentives to cover bad performance, incentives for firms that need financing are likely to be stronger. This is because these firms need cash inflows to fund and expand their regular business and that financial performance is essential for creditors and investors. In fact, Kellogg and Kellogg (1991) find that one of the main reasons for fraud, misrepresentation, and manipulation in a financial statement is to encourage investors to buy an interest in a company's stock as owners or in bonds as creditors. 
Besides the incentives to make financial reports look better, firms that need financing also have the incentives to lower the cost of capital. Prior research finds that lowering the cost of capital is one of the incentives for firms to commit earnings manipulation and that while unidentified earnings manipulation is associated with a lower cost of capital, the cost of capital will be higher if the fraudulent behavior is detected (Dechow, Sloan and Sweeney 1996). This raises the question regarding how managers perceive the payoffs of committing fraud based on the expected likelihood of being caught. Prospect theory (Kahneman and Tversky 2013) states that people tend to be risk-seeking when facing losses and risk-averse when facing gains. Therefore, if we consider the fraud being detected as a loss, managers will tend to be risk-seeking when deciding because they perceive that the probability of being detected is low. Therefore, managers of introduction, growth, and some declining firms have more incentives to commit fraud because firms at these life cycle stages have positive cash flows from financing activities.

Unlike operating and financing activities, which require firms' access to external resources, investing activities involve more internal decisions. Introduction firms and growth firms make large investments to deter entry and obsolescence increases instead of new investments for mature firms. Therefore, cash flows from investing activities are negative for firms at the three life cycle stages. On the other hand, declining firms need to liquidate assets to service debt (Dickinson 2011), so investing cash flow is positive for declining firms. Because investing activities involve internal decisions, there are no incentives associated with investing activities to improve financial reports or lower cost of capital. However, liquidation of assets by declining firms implies financial pressure. 
Therefore, cash flow from investing activities indicates that declining firms are more likely than introduction, growth, and mature firms to commit fraud.

To sum up, incentives to commit fraud are stronger for introduction firms and growth firms because they need significant financing for their growth, and introduction firms are more likely to commit fraud because of their struggle in collecting cash for their operating activities. Mature firms, on the other hand, do not have these incentives. Declining firms also face financial pressure because they likely have to liquidate their assets to pay off debts, as indicated by positive cash flow from investing activities.

Based on the discussion above, our hypothesis is:

H1: Firms' likelihood of committing fraud is different across firms' life cycle stages.

\subsection{Research method}

To determine whether firms at certain life cycle stages are more likely to commit fraud, we carry out three different tests. Firstly, before any multivariate tests, we would like to see whether the proportions of fraud firm years among all firm years within the specific life cycle stages are different across life cycle stages. A Pearson Chi-square test is carried out to test the proportions statistically.

Second, we use a logistic regression model to evaluate firms' likelihood of committing fraud at different life cycle stages. A similar logistic regression model is used in Beasley (1996), Erickson et al. (2006), and Burns and Kedia (2006), which include a dependent variable equal to 1 if fraud occurred in the firm-year, and 0 otherwise. The main variables of interest are indicators for the different firm life cycle stages. As mentioned above, firms are continually moving between the different life cycles to do what is best for the company at that specific time, and firm life cycle stages do not transition monotonically. 
Therefore, we assign a life cycle stage to each firm year according to the signs of cash flows during the fiscal year. The model also includes the natural log of total assets as a control variable. Industry fixed effect is included in the model, and standard errors are clustered at firm level. Therefore, the model is as follows:

$$
\begin{aligned}
\text { Fraud }_{i t}= & \beta_{0}+\beta_{1} \text { Introduction }_{i t}+\beta_{2} \text { Growth }_{i t}+\beta_{3} \text { Mature }_{i t}+\beta_{4} \text { Shake- } \text { out }_{i t} \\
& +\beta_{5} \text { LnAsset }+\beta_{6} \text { Industry Dummy }+\varepsilon_{i t}
\end{aligned}
$$

\begin{tabular}{|c|c|c|}
\hline Fraud & $=$ & 1 if fraud occurred during the year, 0 otherwise; \\
\hline Introduction & $=$ & $\begin{array}{l}1 \text { if cash flows designate the firm as in the introduction } \\
\text { stage for the year, } 0 \text { otherwise; }\end{array}$ \\
\hline Growth & $=$ & $\begin{array}{l}1 \text { if cash flows designate the firm as in the growth stage } \\
\text { for the year, } 0 \text { otherwise; }\end{array}$ \\
\hline Mature & $=$ & $\begin{array}{l}1 \text { if cash flows designate the firm as in the mature stage } \\
\text { for the year, } 0 \text { otherwise; }\end{array}$ \\
\hline Shake-out & $=$ & $\begin{array}{l}1 \text { if cash flows designate the firm as in the shake-out } \\
\text { stage for the year, } 0 \text { otherwise; }\end{array}$ \\
\hline LnAsset & $=$ & Natural log of total assets. \\
\hline
\end{tabular}

Where:

Firm life cycle stages are defined according to Dickinson (2011), which differentiates firm life cycle stages based on the combinations of the signs of cash flows. There are eight possible combinations of the signs of cash flows, which are assigned to five life cycle stages: introduction, growth, mature, shake-out, and decline. A detailed assignment is shown in Figure 3.1. The model above is defined as Model (1) in this study.

Lastly, since incentives and opportunities are the main factors for fraudulent behaviors, we bring in the incentives and opportunities variables from Boyld and LewisWestern (2018) and see if they are different across life cycle stages. We also include a chronological analysis of these variables, following Dickinson (2011). 


\subsection{Samples and empirical results}

\subsection{Samples}

Firm fundamental data are obtained from Compustat and fraud data from the AAER database from 1980 to 2018. In this study, 182 fraud firms are identified with non-missing data. The database includes fraud start and end times for each fraud firm, so we merge the AAER database to Compustat by year and obtained 100,151 firm years. Firms that are in financial and regulated industries are deleted from the sample.

Our percentage test and regression analysis include two main samples, the overall sample, and the matched sample. Each fraud firm is matched with four non-fraud firms with similar sizes in the same industry in the matched sample. For example, if the AAER discloses that firm A commits fraud from 2000 to 2003, four non-fraud firms are found in the same industry with similar total assets in the year 2000. Then firm years from 2000 to 2003 are included for the matched non-fraud firms. The matched sample is used to better access whether the likelihood of committing fraud is due to the life cycle stages or underlying firm characteristics, following Erickson et al. (2005). The overall sample has 100,151 observations, and the matched sample has 1,983 observations. While it is likely that the incentives and opportunities to commit fraud exist during the entire fraud period, it is also possible that the incentives and opportunities only existed in the first year, but the fraud continued to hide detection. Therefore, two additional samples that only use the first year of fraud are included in the analysis. The first includes all observations with available data, while the second a matched sample based on industry and total assets. The incentives and opportunity factors chronological analysis include the overall sample only because it 
is an analysis based on the difference between life cycles the chronology of firms' incentives and opportunities over time and do not involve comparison with non-fraud firms.

\subsection{Empirical results}

Table 3.1 shows the percentages of fraud firm years in the full sample and the matched sample. As is shown in Panel B of Table 3.1, the percentage of fraud firm years is $25.48 \%$ on average. The percentage of fraud firm years is $34.72 \%$ for the introduction stage, $28.18 \%$ for the growth stage, $25.87 \%$ for the decline stage, $20.35 \%$ for the shakeout stage, and $19.72 \%$ for the mature stage. Among all life cycle stages, introduction stage has the highest percentage of fraud firm years, followed by growth and decline stages. Mature stage and shake-out stage have the lowest percentage of fraud firm years. Similar ranks are shown for the one-year sample and one-year matched sample in Table 3.2. A Pearson Chi-square test (p-value 0.000) on the percentages shows that the percentages of fraud firm years in different life cycle stages are significantly different from each other. These results support our hypothesis that firms with negative cash flows from operating activities and positive cash flows from financing activities are more likely to commit fraud. Firms at the growth stage need financing, so the growth stage follows the introduction to the life stage that includes the most percentage of fraud firms. Mature firms have positive cash flows from operating activities and negative cash flows from financing activities, and mature firms have lower incentives to commit fraud. Since sample proportion is the estimator of the population proportion, the results above suggest that the likelihood of fraud is different across firm life cycle stages. Thus, $\mathrm{H} 1$ is supported.

INSERT TABLE 3.1

INSERT TABLE 3.2 
Table 3.3 reports the correlation coefficients between fraud and the different life cycle stages. The correlation coefficient between fraud and introduction and growth stages are positive, while that between fraud and the mature stage is negative. The coefficients between fraud and decline and shake-out stages are not significant.

\section{INSERT TABLE 3.3}

Since Table 3.3 shows that the decline stage is not correlated with fraud, we use the decline stage as the baseline and run a logistic regression using the model (1). Again, the model is run on four different samples. They are labeled the full sample, the matched sample, the one-year sample, and the one-year matched sample, respectively. Table 3.4 shows the results from the model for the two fraud-firm-year samples. For the full sample, the coefficient for introduction stage is significantly positive. The coefficient for mature stage is significantly negative. These are consistent with Table 3.1 and Table 3.2, which indicate that introduction stage is riskier, while mature stage is less risky compared to other firm life cycle stages. For the matched sample, only the coefficient for mature firms is significant and negative. The results from Table 3.4 show that for the full sample of firms, introduction firms are relatively more likely to commit fraud, while mature firms are less likely to do so. These results imply that in general, if a firm has negative cash flows from operating and investing activities and positive cash flows from financing activities only, then the firm is a red flag in terms of the likelihood of committing fraud. If auditors compare an auditee firm to its peers (same industry and similar total assets), mature firms are relatively less likely to commit fraud. It implies that if a firm has positive cash flows from operating activity but negative cash flows from investing and financing activities, 
then the firm is less likely to commit fraud. This implication holds for both the overall sample and the matched sample.

\section{INSERT TABLE 3.4}

Table 3.5 contains the regression results on the one-year sample and one-year matched only. For the one-year sample, the coefficient for introduction stage is positive and significant, while the coefficient for shake-out stage is negative and significant. Consistent with the full sample results, the introduction stage is relatively more likely to be associated with the start of fraud compared to other life cycle stages. However, the shake-out stage seems to be relatively less likely to be associated with the start of fraud. For the one-year matched sample, the coefficient for mature stage is negative and significant, and the coefficient for shake-out firm is negative and marginally significant. The results imply that if a firm is at the mature stage, it is less likely to start to commit fraud than its industry and size peers, while introduction and growth stage does not impact the likelihood of beginning to commit fraud. The results on the one-year samples are consistent with the full samples by showing that introduction firms are relatively more likely to commit fraud, but mature firms are less likely to commit fraud, compared to declining firms-the baseline. However, a significant difference lies in shake-out stage between the full samples and the one-year samples. Shake-out firms are less likely to start fraud than declining firms but are not significantly different from declining firms in terms of impacting the likelihood of fraud during the fraud.

\section{INSERT TABLE 3.5}

Chronological analyses on incentive and opportunity factors are shown in Table 3.6 and 3.7, respectively. Like Boyld and Lewis-Western (2018), we include four incentive 
factors: Need Capital, Inconsistent Fundamental Signals, Low Cash and High Debt, and Competitive Industry and Declining Margins. The sample size comes down to 77,304 because of missing data for incentives and opportunities factor variables. It appears that introduction and decline firms have higher incentives to raise capital, and mature firms have the lowest need for capital. Similar trends exist for cash and debt structures as well. Results for inconsistent fundamental signals and competitive industry and declining margins do not show significant differences. Results for opportunity-complexity show that mature firms and growth firms have the highest complexity and introduction score, and declining firms have the lowest complexity score. It is likely that introduction firms focus more on profitability and growth and do not spend much efforts on increasing foreign sales or mergers and acquisitions. However, introduction firms and decline firms have higher scores for internal control weakness.

\section{INSERT TABLE 3.6}

\subsection{Summary and conclusions}

This study explores whether firm life cycle stages are associated with the likelihood of fraud. The analysis provides evidence that introduction stage has the highest proportion of fraud firm years, followed by growth firms. Decline and shake-out firms are in the middle, and mature firms are less likely to commit fraud. Regression results are consistent with the percentage analysis and the correlation coefficient table, but with mixed significance. We find that some life cycle stages matter for the overall sample, such as introduction stage, which is riskier for both the full samples and the one-year samples. Also, mature stage seems to be less risky among firm peers for both the full samples and the oneyear samples. The shake-out stage is relatively less risky in terms of starting the fraud. 
There are several contributions to this paper. First of all, it adds to the literature by finding additional variables associated with the likelihood of fraud. Second, this study finds that fraud risk is different across different life cycle stages. Introduction firms are riskier than other life cycle stages, and the mature stage is less risky in terms of committing fraud. Lastly, the paper can help investors to detect and predict fraud more efficiently.

One limitation of this study is that the AAER database contains only the firms identified as fraud firms by the SEC. As a result, the no-fraud sample potentially includes the observations that had fraud but were not detected by the SEC. Second, the variables that are associated with fraud are not studied exhaustedly, so potential omitted variable bias could exist in the model. An implication but not limitation of this study is that even though growth and decline firms are found not as risky as introduction firms, they should not be considered as carrying "low" risk. No life cycle stages have been found to be "free" from fraud, so all the firms should be audited thoroughly; only more attention should be paid to introduction firms. 


\section{References:}

Anthony, J.H. and Ramesh, K. 1992. Association between accounting performance measures and stock prices: A test of the life cycle hypothesis. Journal of Accounting and economics 15(2-3): 203-227.

Beasley, M.S. 1996. An empirical analysis of the relation between the board of director composition and financial statement fraud. Accounting review: 443-465.

Beasley, M.S., Carcello, J.V., Hermanson, D.R. and Lapides, P.D. 2000. Fraudulent financial reporting: Consideration of industry traits and corporate governance mechanisms. Accounting Horizons 14(4): 441-454.

Bell, T.B. and Carcello, J.V. 2000. A decision aid for assessing the likelihood of fraudulent financial reporting. Auditing: A Journal of Practice \& Theory 19(1): 169-184.

Boschen, J.F., Duru, A., Gordon, L.A. and Smith, K.J. 2003. Accounting and stock price performance in dynamic CEO compensation arrangements. The Accounting Review 78(1): 143-168.

Boyle, E.S. and Lewis-Western, M.F. 2018. The value-add of an audit in a post-SOX world. Available at SSRN 2745433.

Burns, N. and B. Kedia. 2006. The Impact of Performance-Based Compensation on Misreporting. Journal of Financial Economics 79 (1): 35-67.

Carpenter, T.D. 2007. Audit team brainstorming, fraud risk identification, and fraud risk assessment: Implications of SAS No. 99. The Accounting Review 82(5): 1119-1140.

Graham, J.R., Harvey, C.R. and Rajgopal, S. 2005. The economic implications of corporate financial reporting. Journal of accounting and economics 40(1-3): 3-73.

Choi, J., Choi, W. and Lee, E. 2016. Corporate life cycle and earnings benchmarks. Australian Accounting Review 26(4): 415-428.

Clor-Proell, S.M., Kaplan, S.E. and Proell, C.A. 2015. The impact of budget goal difficulty and promotion availability on employee fraud. Journal of business ethics 131(4): 773-790.

Collins, D.W., Gong, G. and Li, H. 2009. Corporate governance and backdating of executive stock options. Contemporary Accounting Research 26(2): 403-445. 
Dechow, P.M., Sloan, R.G. and Sweeney, A.P. 1996. Causes and consequences of earnings manipulation: An analysis of firms subject to enforcement actions by the SEC. Contemporary accounting research 13(1): 1-36.

Dickinson, V. 2011. Cash flow patterns as a proxy for firm life cycle. The Accounting Review 86 (6): 1969-1994.

Dickinson, V., Kassa, H. and Schaberl, P.D. 2018. What information matters to investors at different stages of a firm's life cycle? Advances in accounting (42): 22-33.

Diamond, D. 1991. Monitoring and reputation: The choice between bank loans and directly placed debt. Journal of Political Economy 99 (4): 689-721.

Dorminey, J., Fleming, A.S., Kranacher, M.J. and Riley Jr, R.A. 2012. The evolution of fraud theory. Issues in accounting education 27(2): 555-579.

Drake, K.D. and Martin, M.A. 2020. Implementing relative performance evaluation: The role of life cycle peers. Journal of Management Accounting Research 32(2): 107135.

Elsayed, K. and Paton, D. 2009. The impact of financial performance on environmental policy: does firm life cycle matter? Business Strategy and the Environment 18(6): 397-413.

Erickson, M., M. Hanlon and E.L. Maydew. 2006. Is There a Link between Executive Equity Incentives and Accounting Fraud? Journal of Accounting Research 44 (March): 113-144.

Faff, R., Kwok, W.C., Podolski, E.J. and Wong, G. 2016. Do corporate policies follow a life-cycle? Journal of Banking \& Finance (69): 95-107.

Farber, D.B. 2005. Restoring trust after Fraud: Does corporate governance matter? The Accounting Review 80(2): 539-561.

Gao, Y., Kim, J.B., Tsang, D. and Wu, H. 2017. Go before the whistle blows: an empirical analysis of director turnover and financial fraud. Review of Accounting Studies 22(1): 320-360. 
Graham, J.R., Harvey, C.R. and Rajgopal, S. 2005. The economic implications of corporate financial reporting. Journal of accounting and economics 40(1-3): 3-73.

Gordon, E.A., E. Henry, T.J. Louwers and B.J. Reed. 2007. Auditing Related Party Transactions: A Literature Overview and Research Synthesis. Accounting Horizons 21 (March): 81-102.

Hasan, M.M., Hossain, M. and Habib, A. 2015. Corporate life cycle and cost of equity capital. Journal of Contemporary Accounting \& Economics 11 (1): 46-60.

Habib, A. and Hasan, M.M. 2017. Firm life cycle, corporate risk-taking and investor sentiment. Accounting \& Finance 57 (2): 465-497.

Hansen, J.V., McDonald, J.B., Messier Jr, W.F. and Bell, T.B. 1996. A generalized qualitative-response model and the analysis of management fraud. Management Science 42(7): 1022-1032.

Hogan, C.E., Rezaee, Z., Riley Jr, R.A. and Velury, U.K. 2008. Financial statement fraud: Insights from the academic literature. Auditing: A Journal of Practice \& Theory 27 (2): 231-252.

Hribar, P. and Yehuda, N. 2015. The mispricing of cash flows and accruals at different lifecycle stages. Contemporary Accounting Research 32(3): 1053-1072.

Kahneman, D. and Tversky, A. 2013. Prospect theory: An analysis of decision under risk. In Handbook of the fundamentals of financial decision making: Part I: 99-127.

Kellogg, O. and Kellogg, L.B. 1991. Fraud, Window Dressing, and Negligence in Financial Statements. Commercial Law Series, McGraw-Hill.

Liu, Michelle M. 2006. Accruals and managerial operating decisions over the firm life cycle. Diss. Massachusetts Institute of Technology.

Myers, S. 1984. The capital structure puzzle. Journal of Finance 39 (3): 575-592.

Matsunaga, S.R. and Park, C.W. 2001. The effect of missing a quarterly earnings benchmark on the CEO's annual bonus. The Accounting Review 76(3): 313-332. 
Payne, J.L. and Robb, S.W. 2000. Earnings management: The effect of ex ante earnings expectations. Journal of Accounting, Auditing \& Finance 15(4): 371-392.

Perri, F.S. and Brody, R.G. 2012. The optics of fraud: affiliations that enhance offender credibility. Journal of Financial Crime 19(4): 355-370.

Trompeter, G.M., Carpenter, T.D., Desai, N., Jones, K.L. and Riley, R.A. 2013. A synthesis of fraud-related research. AUDITING: A Journal of Practice, 32(Supplement 1): 287-321.

Wilks, T.J. and Zimbelman, M.F. 2004. Using game theory and strategic reasoning concepts to prevent and detect fraud. Accounting horizons 18(3): 173-184. 


\section{Figure 3.1}

\section{Firm life cycle stages according to the signs of cash flows}

$\begin{array}{lcccccc} & 1 & 2 & 3 & 4 & 5 & 6 \\ & \text { Introduction } & \text { Growth } & \text { Mature } & \text { Shake-Out } & \text { Shake-Out } & \text { Decline } \\ \begin{array}{c}\text { Cash flow from } \\ \text { operating activities }\end{array} & - & + & + & - & + & - \\ \begin{array}{c}\text { Cash flow from } \\ \text { investing activities }\end{array} & - & - & - & - & + & + \\ \begin{array}{c}\text { Cash flow from } \\ \text { financing activities }\end{array} & + & + & - & - & +/- & +/-\end{array}$

Source: Dickinson (2011)

Dickinson (2011) assigns firm life cycle stages according to the signs of cash flows. For example, if a firm has negative cash flows from operating activities and investing activities, but positive cash flows from financing activities, then the firm is at introduction stage. This firm life cycle stage is non-linear, which means that the life cycle stages do not follow a sequential pattern. For example, Coca-Cola company was at mature stage from the year 1990 to the year 2007, but it was at growth stage in 2008, and CVS company went from decline stage to growth stage from 1997 to 1998. 
Table 3.1 Total fraud percentages - Fraud firm years

Panel A: The 1-4 matched sample

\begin{tabular}{ccccc}
\hline Life Cycle & N & Fraud & Percentage & Mean \% \\
\hline Introduction & 360 & 125 & $34.72 \%$ & $25.48 \%$ \\
Growth & 589 & 166 & $28.18 \%$ & $25.48 \%$ \\
Mature & 710 & 140 & $19.72 \%$ & $25.48 \%$ \\
Decline & 143 & 37 & $25.87 \%$ & $25.48 \%$ \\
Shake-out & 172 & 35 & $20.35 \%$ & $25.48 \%$ \\
\hline
\end{tabular}

Chi-square $=100.252 ;$ p-value $=0.000$

Panel B: The overall sample

\begin{tabular}{ccccc}
\hline Life Cycle & $\mathbf{N}$ & Fraud & Percentage & Mean \% \\
\hline Introduction & 16,417 & 125 & $7.6 \%$ & $5 \%$ \\
Growth & 26,769 & 166 & $6.2 \%$ & $5 \%$ \\
Mature & 39,157 & 140 & $3.6 \%$ & $5 \%$ \\
Decline & 8,268 & 37 & $4.5 \%$ & $5 \%$ \\
Shake-out & 9,540 & 35 & $3.7 \%$ & $5 \%$ \\
\hline
\end{tabular}

Chi-square $=52.055 ;$ p-value $=0.000$ 
Table 3.2 Total fraud percentages - First year of fraud

Panel A: The 1-4 matched sample

\begin{tabular}{ccccc}
\hline Life Cycle & $\mathbf{N}$ & Fraud & Percentage & Mean \% \\
\hline Introduction & 141 & 49 & $34.75 \%$ & $24.76 \%$ \\
Growth & 243 & 68 & $27.98 \%$ & $24.76 \%$ \\
Mature & 234 & 41 & $17.52 \%$ & $24.76 \%$ \\
Decline & 55 & 15 & $27.27 \%$ & $24.76 \%$ \\
Shake-out & 62 & 9 & $14.52 \%$ & $24.76 \%$ \\
\hline
\end{tabular}

Chi-square $=58.592 ;$ p-value $=0.000$

Panel B: The overall sample

\begin{tabular}{ccccc}
\hline Life Cycle & $\mathbf{N}$ & Fraud & Percentage & Mean \% \\
\hline Introduction & 1,451 & 49 & $3.38 \%$ & $2.26 \%$ \\
Growth & 2,614 & 68 & $2.6 \% \%$ & $2.26 \%$ \\
Mature & 2.183 & 41 & $1.88 \%$ & $2.26 \%$ \\
Decline & 808 & 15 & $1.86 \%$ & $2.26 \%$ \\
Shake-out & 999 & 9 & $0.9 \%$ & $2.26 \%$ \\
\hline
\end{tabular}

Chi-square $=14.257 ;$ p-value $=0.07$ 
Table 3.3 Correlation coefficient table - Overall sample on fraud firm years $(n=102,686)$

\begin{tabular}{|c|c|c|c|c|c|c|}
\hline & Fraud & Introduction & Growth & Mature & Decline & Shake-out \\
\hline Fraud & 1.000 & 0.017 & 0.011 & -0.015 & -0.002 & -0.006 \\
\hline Introduction & 0.017 & 1.000 & -0.259 & -0.342 & -0.129 & -0.140 \\
\hline \multirow[t]{2}{*}{ Growth } & 0.011 & -0.259 & 1.000 & -0.466 & -0.176 & -0.190 \\
\hline & 0.000 & $<.0001$ & & $<.0001$ & $<.0001$ & $<.0001$ \\
\hline Mature & -0.015 & -0.342 & -0.466 & 1.000 & -0.232 & -0.251 \\
\hline Decline & 0.557 & $<.0001$ & $<.0001$ & $<.0001$ & & $<.0001$ \\
\hline \multirow[t]{2}{*}{ Shake-out } & -0.006 & -0.140 & -0.190 & -0.251 & -0.095 & 1.000 \\
\hline & 0.069 & $<.0001$ & $<.0001$ & $<.0001$ & $<.0001$ & \\
\hline
\end{tabular}

The numbers above the diagonal are the Pearson correlations, and the numbers below the diagonal are Spearman correlations. 
Table 3.4 Regression results - Fraud firm years

\begin{tabular}{lcc}
\hline LnAsset & $\begin{array}{c}\text { Overall } \\
\text { fraud }\end{array}$ & $\begin{array}{c}\text { Matched } \\
\text { fraud }\end{array}$ \\
\hline $\begin{array}{l}0.172^{* * *} \\
(0.0362)\end{array}$ & $\begin{array}{c}0.189^{* * *} \\
(0.0437)\end{array}$ \\
Introduction & $0.726^{* * *}$ & 0.365 \\
& $(0.196)$ & $(0.248)$ \\
Growth & 0.119 & -0.238 \\
& $(0.226)$ & $(0.261)$ \\
Mature & & $-0.706^{* * *}$ \\
& $-0.473^{*}$ & $(0.273)$ \\
Shake-out & $(0.242)$ & \\
\hline Intercept & & -0.475 \\
& -0.275 & $(0.299)$ \\
& $(0.263)$ & $-1.825^{* * *}$ \\
& & $(0.296)$ \\
& $-6.253^{* * *}$ & \\
\hline
\end{tabular}

Standard errors in parentheses $\quad{ }^{*} p<0.10,{ }^{* *} p<0.05,{ }^{* * *} p<0.01$ 
Table 3.5 Regression results - First year of fraud

\begin{tabular}{|c|c|c|}
\hline & $\begin{array}{l}\text { Overall } \\
\text { fraud }\end{array}$ & $\begin{array}{c}\text { Matched } \\
\text { fraud }\end{array}$ \\
\hline LnAsset & $\begin{array}{l}0.156^{* * *} \\
(0.0303)\end{array}$ & $\begin{array}{l}0.154^{* * *} \\
(0.0400)\end{array}$ \\
\hline Introduction & $\begin{array}{l}0.679^{* *} \\
(0.292)\end{array}$ & $\begin{array}{c}0.223 \\
(0.351)\end{array}$ \\
\hline Growth & $\begin{array}{l}0.0612 \\
(0.282)\end{array}$ & $\begin{array}{l}-0.339 \\
(0.347)\end{array}$ \\
\hline Mature & $\begin{array}{l}-0.219 \\
(0.297)\end{array}$ & $\begin{array}{c}-0.920^{* *} \\
(0.360)\end{array}$ \\
\hline Shake-out & $\begin{array}{c}-0.990^{* *} \\
(0.429)\end{array}$ & $\begin{array}{l}-0.920^{*} \\
(0.474)\end{array}$ \\
\hline Intercept & $\begin{array}{c}-4.660^{* * *} \\
(0.301)\end{array}$ & $\begin{array}{c}-1.563^{* * *} \\
(0.338)\end{array}$ \\
\hline$N$ & 8,100 & 741 \\
\hline
\end{tabular}

Standard errors in parentheses $* p<0.10, * * p<0.05, * * * p<0.01$ 
Table 3.6 Incentives Factors by Life Cycle Stage

\begin{tabular}{|c|c|c|c|c|c|c|}
\hline & Pooled & Introduction & Growth & Mature & Shake-out & Decline \\
\hline \multicolumn{7}{|c|}{$\underline{\text { Need Capital }}$} \\
\hline $\mathrm{t}$ & 0.18 & 0.8 & 0.03 & 0.02 & 0.12 & 0.86 \\
\hline $\mathrm{t}+1$ & 0.16 & 0.77 & 0.02 & 0.01 & 0.11 & 0.87 \\
\hline$t+2$ & 0.16 & 0.71 & 0.03 & 0.02 & 0.11 & 0.8 \\
\hline \multicolumn{7}{|c|}{$\underline{\text { Inconsistent Fundamental Signals }}$} \\
\hline $\mathrm{t}$ & 0.17 & 0.18 & 0.15 & 0.18 & 0.16 & 0.19 \\
\hline $\mathrm{t}+1$ & 0.17 & 0.18 & 0.15 & 0.18 & 0.16 & 0.19 \\
\hline$t+2$ & 0.17 & 0.19 & 0.15 & 0.18 & 0.15 & 0.19 \\
\hline
\end{tabular}

$\underline{\text { Low Cash, High Debt }}$

$\begin{array}{lllllll}\mathrm{t} & 0.14 & 0.21 & 0.13 & 0.11 & 0.15 & 0.17 \\ \mathrm{t}+1 & 0.14 & 0.23 & 0.14 & 0.1 & 0.15 & 0.18 \\ \mathrm{t}+2 & 0.14 & 0.22 & 0.13 & 0.11 & 0.15 & 0.18\end{array}$

Competitive Industry, Declining Margins

\begin{tabular}{ccccccc}
$\mathrm{t}$ & 0.06 & 0.06 & 0.06 & 0.07 & 0.05 & 0.05 \\
$\mathrm{t}+1$ & 0.06 & 0.05 & 0.05 & 0.07 & 0.04 & 0.04 \\
$\mathrm{t}+2$ & 0.05 & 0.05 & 0.05 & 0.06 & 0.04 & 0.05 \\
\hline $\mathrm{N}$ & 77,304 & 9,284 & 24,354 & 31,325 & 7,709 & 4,632 \\
$\begin{array}{c}\% \text { of } \\
\text { total } \mathrm{n}\end{array}$ & $100.00 \%$ & $12.01 \%$ & $31.50 \%$ & $40.52 \%$ & $9.97 \%$ & $5.99 \%$ \\
\hline
\end{tabular}


Table 3.7 Opportunities Factors by Life Cycle Stage

\begin{tabular}{|c|c|c|c|c|c|c|}
\hline & Pooled & Introduction & Growth & Mature & Shake-out & Decline \\
\hline \multicolumn{7}{|c|}{ Complexity } \\
\hline $\mathrm{t}$ & 0.16 & 0.09 & 0.18 & 0.18 & 0.12 & 0.07 \\
\hline$t+1$ & 0.17 & 0.09 & 0.18 & 0.2 & 0.13 & 0.07 \\
\hline$t+2$ & 0.17 & 0.09 & 0.18 & 0.21 & 0.15 & 0.08 \\
\hline \multicolumn{7}{|c|}{ Internal Control Weakness } \\
\hline $\mathrm{t}$ & 0.03 & 0.06 & 0.02 & 0.02 & 0.03 & 0.04 \\
\hline $\mathrm{t}+1$ & 0.03 & 0.06 & 0.03 & 0.02 & 0.03 & 0.05 \\
\hline$t+2$ & 0.03 & 0.07 & 0.03 & 0.02 & 0.04 & 0.05 \\
\hline $\mathrm{N}$ & 77,304 & 9,284 & 24,354 & 31,325 & 7,709 & 4,632 \\
\hline $\begin{array}{c}\% \text { of } \\
\text { total } n\end{array}$ & $100.00 \%$ & $12.01 \%$ & $31.50 \%$ & $40.52 \%$ & $9.97 \%$ & $5.99 \%$ \\
\hline
\end{tabular}




\title{
CHAPTER FOUR: NONPROFIT RATINGS AND PAY-TO-PERFORMANCE SENSITIVITY
}

\author{
Chen Zhao \\ John Chambers College of Business and Economics \\ West Virginia University \\ chzhao@mix.wvu.edu
}

\section{Author Note}

Submitted in partial fulfillment of Ms. Zhao's requirements for the degree of Doctor of Philosophy in Accounting at West Virginia University. The corresponding author may be reached atchzhao@mix.wvu.edu.

\section{Acknowledgment}

I would like to give special thanks to my dissertation chair, Dr. Richard Dull for generously sharing the nonprofit organization IRS Form 990 database to be used in this study. 


\begin{abstract}
Prior studies on agency theory suggest that agency problems exist in both for-profit organizations and nonprofit organizations. CEO compensation is associated with agency problems in nonprofit organizations (Core, Guay, and Verdi 2006). Aggarwal, Evans, and Nanda (2012) found evidence that board size is negatively associated with pay-to-performance sensitivity for nonprofit organizations. However, since donors are fund providers of nonprofit organizations, it is also likely that donors have strong incentives to carry out the monitoring role externally. The monitoring role of donors is limited to the donors' ability to acquire nonprofit organization information, but charity rating agencies make the information more accessible and understandable. Given that prior research find that donors dislike high CEO compensation (Balsam and Harris 2014), this study focuses on whether charity rating availability is associated with negative pay-toperformance sensitivity. Using a sample derived from e-filed IRS Form 990s and Charity Navigator rating records, this study provides evidence that rating availability is negatively related to pay-to-performance sensitivity for nonprofit organizations. Additional tests provide evidence that the overall rating score and financial rating score are negatively associated with pay-toperformance sensitivity.
\end{abstract}


Hit the top and you became a target. Your board starts asking questions about comparable compensation and folks in general just start making comments - and not of the "you're worth every penny" variety.

--Joan Garry, former CEO of a nonprofit organization

\subsection{INTRODUCTION}

Nonprofit organizations compete with other nonprofit organizations and even for-profit organizations for talented leaders. As a result, they must offer competitive compensation packages to attract and retain those leaders. However, nonprofit organizations with higher-paid CEOs often become targets of controversy. Donors dislike high CEO compensation because high compensation indicates that more of their donation is used to pay personnel instead of being used for the organization's mission (Balsam and Harris 2014). Therefore, donors have the incentive to monitor nonprofit organizations and CEO compensation.

However, not all donors seek IRS Form 990 information (Balsam and Harris 2014). Form 990 is the informational form filed by nonprofit organizations as required by the IRS. Form 990 includes a wide range of information about the operations of a nonprofit organization, including financial and limited personnel information. The form is considered public information and many organizations post the forms on their website. However, not all donors are capable of understanding the financial information of nonprofit organizations or might not find it costeffective to do so (Balsam and Harris 2014). Therefore, even though Form 990 information is publicly available, not all donors will seek the forms for data.

As is indicated by Balsam and Harris (2014) small donors do not generally react to the disclosure of nonprofit organization CEO compensation. Charity rating agencies provide nonprofit rating information based on the analysis of Form 990 and other qualitative characteristics of 
nonprofit organizations (Harris and Neely 2016; Charity Navigator 2020). The information provided by the rating agencies are easier to access and understand for the donors, and prior research has found evidence that donors use information issued by charity rating agencies to make donation decisions (Sloan 2008; Gordon, Knock, and Keely 2009; Chen 2009; Grant 2010; and Harries and Neely 2016). Therefore, it is likely that donors play a more substantial monitoring role for rated organizations than for those organizations that are not rated. The purpose of the current study is to understand the relationship between organization rating and CEO pay-to-performance sensitivity.

Pay-to-performance sensitivity is used in both nonprofit and for-profit literature to indicate monitoring characteristics. Ke, Petroni, and Safieddine (1999) study the association between ownership concentration and pay-to-performance sensitivity and find that firm monitoring is associated with ownership concentration. Aggarwal, Evans, and Nanda (2012) also find that nonprofit board size impacts pay-to-performance sensitivity in nonprofit organizations. Baber, Daniel, and Roberts (2002) provide evidence that nonprofit organization CEO compensation is associated with performance. Specifically, an increase in CEO performance corresponds with an increase in compensation. However, different monitoring types will impact the magnitude of the increase in compensation following an improvement in nonprofit organization performance, (i.e., a change in total revenue and/or a change in the program spending ratio).

Charity rating agencies provide rating information of nonprofit organizations which allows donors to make informed donation decisions. The rating scores are based on analyses of the financial information of the nonprofit organization provided on Form 990 and the accountability and transparency information of the nonprofit organizations. The roles of charity rating agencies are similar to those of financial analysts, who act as information intermediaries between investors 
and public firms. They provide evaluation reports based on their analyses of firm financial statements, and these evaluation reports are easier to assess than the raw data to investors. Financial analysts play an essential role in the market because not all investors find it cost-effective to access firms' financial statements, nor do they all have the special knowledge to process the financial information. Like financial analysts, charity rating agencies rely on nonprofit organizations' financial statements on Form 990, as well as other organization information (i.e. organization governance) to provide donors with rating information, which is easier to understand and more accessible to the donors. Therefore, it is more cost-effective for donors to seek information from charity rating agencies before making donating decisions.

Prior research has found evidence of donors' use of third-party rating information (Sloan 2008; Chen 2009; and Grant 2010) and that a(n) increase (decrease) in charity rating is associated with $\mathrm{a}(\mathrm{n})$ increase (decrease) in the amount of donations afterward (Gordon, Knock, and Neely 2009). Charity agencies also provide sorting tools ordered by rating, as well as "top" lists. Therefore, rated organizations will have more public exposure to donors than non-rated organizations. Given that donors dislike high CEO compensation (Balsam and Harris 2014; Balsam and Harris 2018), organizations with increased public exposure may feel pressured to maintain a lower level of CEO compensation. Therefore, CEO compensation is likely to be lower in the rated organizations because of higher social pressure from public exposure, controlling for CEO performance.

This paper's sample contains 271,068 organization years from the year 2010 to the year 2017 , with 18,436 organization years as rated organization years. Results of the model show that rated organization years have lower pay-to-performance sensitivity than non-rated organization years. High overall and financial rating scores are also found to be negatively associated with pay- 
to-performance sensitivity. These findings provide evidence that donors likely play a significant monitoring role through rating information.

This research contributes to the existing literature on nonprofit organization monitoring in several ways. First, this study complements the literature on charity rating and finds that charity rating is associated with nonprofit organizations' pay-to-performance sensitivities. Specifically, pay-to-performance sensitivity is lower for rated organizations. The results provide additional evidence that donors use third-party information to make decisions. Second, this paper adds to the nonprofit organization governance and monitoring literature and finds that charity rating agencies' role as information intermediaries also contributes to the external monitoring of nonprofit organizations. Since donors have easier access to nonprofit organization characteristics through these agencies, monitoring is feasible for donors through the rating agencies. Aggarwal et al. (2012) find evidence of nonprofit organizations' insider governance role, but this study complements nonprofit organizations' monitoring by finding evidence of external monitoring on nonprofit organizations. Third, it contributes to the nonprofit organization's executive compensation literature and provides additional evidence that executive compensation is less sensitive to CEO performance under public exposure.

The following section provides background and hypothesis. Section 3 explains the samples, and Section 4 is empirical results. The last section is the conclusion.

\subsection{BACKGROUND AND HYPOTHESIS:}

Agency problem exists in for-profit firms because ownership and management of the firms are separated, and the conflict of interest may result in management behaving in a way that does not maximize value for the owners (Jensen and Meckling 2019). Research has developed practices to mitigate agency problems, such as tying executive pay to performance and introducing board 
and internal auditors to monitor management behavior (Mehran 1995; Klein 2002; and Bebchuk and Fried 2003), to maximize stockholders' welfare. Like for-profit firms, nonprofit organizations can face serious agency problems. Donors provide funds to nonprofit organizations expecting management to do their best to realize organization missions, while managers have the incentives to expropriate these funds (Fama and Jensen 1983). Prior research on agency problems in the nonprofit sector focuses on the role of nonprofit boards. Studies have shown that increased board oversight is associated with lower agency costs (Brickley, Van Horn, and Wedig 2003; Callen, Klein, and Tinkelman 2003). Aggarwal et al. (2012) also find that board size is positively associated with nonprofit organization performance measures. However, nonprofit boards are often dominated by insiders, and the monitoring role of these boards is eliminated (Fama and Jensen 1983). Also board members tend to be pushed by management to focus on fundraising instead of monitoring activities (O'Regan and Oster 2005). Therefore, even though nonprofit boards play a monitoring role, this role is often limited.

On the other hand, donors have substantial incentives to monitor nonprofit organizations. Donors are fund providers, and they would like the funds to be spent to realize organization missions. Fisman and Hubbard (2003) find that donors play an essential role in monitoring organizations if board oversight is not stringent. Gaver and Im (2014) also provide evidence that excess CEO compensation is negatively related to external funding, supporting the view that fund providers' demand for monitoring is associated with agency costs in nonprofit organizations.

Despite donors' strong incentives to monitor nonprofit organizations, their monitoring tools are often limited. Nonprofit organizations file IRS Form 990, where they disclose balance sheet, cash flow statements, and executives' payment statements. However, not all donors are capable of understanding the information on the IRS forms. It is also not cost-effective for smaller 
donors to seek out financial information, and they may not even know where to find it (Tinkelman 1998; Yetman and Yetman 2013). Balsam and Harris (2014) find evidence that sophisticated donors react to executive compensation, while small donors do not. Given that most donors are smaller donors (Balsam and Harris 2014), donors' monitoring role is likely to be limited because of nonprofit organization information accessibility.

The same information accessibility issue exists in the for-profit world since not all investors could interpret financial reports. However, investors rely on financial analysts who analyze firm financial information and issue evaluation reports. These evaluation reports are more understandable and accessible to the investors, which allows more access to financial information for the investors and reduces information asymmetry between firms and investors.

Like financial analysts for the for-profit world, charity rating agencies act as information intermediaries between donors and nonprofit organizations. The rating agencies evaluate the performance of nonprofit organizations and issue evaluation reports for the donors. Generally, the rating agencies provide the donors with a rating score or a rating rank, or both, on the rated organizations. The rating is based on a compounding analysis of different dimensions of nonprofit organization characteristics. For example, the rating agency used in this study is Charity Navigator3. Charity Navigator claims to be the largest and most used charity rating agency (Charity Navigator 2020), and it rates about 9,000 organizations annually. Charity Navigator evaluates nonprofit organizations on two dimensions, financial and accountability. They develop financial ratios to evaluate financial efficiency and capacity using the financial information on

\footnotetext{
${ }^{3}$ Following Gordon, Knock and Neely (2009), this study uses Charity Navigator as rating agency. Charity Navigator is the only rating agency that provides historical rating records for nonprofit organizations and provide the highest number of observations in this study. Also, Charity Navigator was listed by Badal (2007) as one of the best information sources on charities.
} 
Form 990. They also assess nonprofit accountability utilizing the information from Form 990 and the organization's websites. Once these two dimensions are assessed, Charity Navigator will calculate an organization's overall score and issue both a rating score and a rating rank4. The ratings reveal the nonprofit organizations' financial health and governance effectiveness to donors, allowing donors to have indirect but easy access to nonprofit organizations' information. Therefore, rating agencies provide a tool for donors to carry out their monitoring roles. Theoretical framework of this study is shown in Figure 4.1.

\section{INSERT FIGURE 4.1}

Prior research has confirmed donors' use of third-party information to make donation decisions (Sloan 2008; Chen 2009; Grant 2010). Gordon et al. (2009) also provide evidence that a higher rating is associated with more donations. Comparing rated or not-rated organizations, Harris and Neely (2016) find significantly more donations to rated organizations than to not-rated organizations. These findings suggest that rated organizations will receive more public exposure than not-rated organizations and provide additional support to the argument that donors reach out for third-party information about nonprofit organizations. Because of the public exposure of rated nonprofit organizations, donors' monitoring is likely stronger for rated organizations. Therefore, my first hypothesis is:

H1: Controlling for nonprofit organization size, CEO compensation is lower in nonprofit organizations that are rated by rating agencies compared to that in nonprofit organizations that are not rated by rating agencies.

\footnotetext{
${ }^{4}$ See https://www.charitynavigator.org/index.cfm?bay=content.view\&cpid=5593\#rating
} 
Baber, Daniel, and Roberts (2002) find that CEO compensation is associated with accounting measures, namely revenues and program spending ratios5, which implies that CEO compensation captures performance information. Therefore, CEOs who can generate more revenues are in high demand, and organizations need to offer enough compensation to attract these talented leaders. On the other hand, higher CEO compensation increases the scrutiny of nonprofit organizations (Boroff 2008; Banjo 2009; Wilhelm 2009; Gershman 2011), and Balsam and Harris (2014) find that donors react negatively to the disclosure of high executive compensation. Bonuses are also found to be negatively associated with donations (Balsam and Harris 2018). Even though donors dislike high executive compensations in nonprofit organizations, high CEO compensation does not necessarily indicate agency problems unless it comes with poor performance. To rule out the impact of management performance on CEO compensation, research on nonprofit organization agency problems typically study pay-to-performance sensitivity and compares whether the payto-performance sensitivity is associated with any other variable that could impact nonprofit governance monitoring. For example, Aggarwal et al. (2012) find evidence that nonprofit board size is negatively related to pay-to-performance sensitivity for nonprofit organizations. Specifically, for the same improvement in CEO performance, the increase in compensation will be lower if the board size is larger. The results imply that nonprofit organization boards play a monitoring role in organizational governance and that the larger the board's size, the stronger the monitoring role. This study is to extend the Aggarwal et al. (2012) paper by studying the role of external monitors of nonprofit organizations. As is discussed above, donors have the incentives to monitor nonprofit organizations, and the charity rating agencies provide the donors with easy, accessible, and understandable information about nonprofit organizations. This study investigates

\footnotetext{
${ }^{5}$ Program spending ratio=Total Program Spending Expenses/Total Revenue
} 
whether the availability of charity rating information is associated with nonprofit organization CEO pay-to-performance sensitivity.

Charity Navigator interprets financial information of nonprofit organizations and issues rating scores and rating ranks. Prior research has confirmed donors' use of rating information (Gordon et al. 2009; Harris and Neely 2016). Therefore, the rated organizations receive more public exposure and provide donors with useful tools to monitor nonprofit organizations. Agency problems in these rated organizations are thus likely to be alleviated. Because donors look unfavorably at high compensation, the pay-to-performance sensitivity will likely be lower for the rated organizations. Therefore, my second hypothesis is:

H2: Pay-to-performance sensitivity is lower for nonprofit organizations that are rated by charity rating agencies compared to that for nonprofit organizations that are not rated by rating agencies.

According to Fama and Jensen (1983), monitoring in nonprofit organizations is different from that in the for-profit world because there are no "owners" in nonprofit organizations and no one claims the residual value of the organizations. However, donors look unfavorably at higher CEO compensation. According to Balsam and Harris (2014), donations from donors who rely on financial reports (sophisticate donors) are negatively associated with CEO compensation. Balsam and Harris (2018) also find that donation is negatively associated with CEO bonus pay from the prior period. Other research also finds that donors use third-party information to make donating decisions (Sloan 2008; Chen 2009; and Grant 2010) and that higher ratings is associated with more donations (Harris and Neely 2016). In an extensive search, no research was found that addressed the monitoring role of donors This gap in nonprofit research is interesting because even though donors contribute to nonprofit organizations, they are not owners, nor do they generally have a 
specific impact on the operations. Despite the limitations of the donors' direct monitoring role in the nonprofit organizations, public exposure can pressure the CEOs to do what is right instead of seeking personal benefits. Moreover, donors also have the incentives to monitor the activities of the organizations' management to confirm that their donations are used to contribute to the program mission and they do not like any inappropriate financial compensations (Fisman and Hubbard 2003). Therefore, high ratings are likely to be associated with higher public exposure, and both reduced information asymmetry and increased public exposure can alleviate agency problems and lead to lower CEO compensation.

As is discussed above, donors dislike higher compensation, so organizations with high public exposure have the incentives not to compensate their CEOs with high salaries. Moreover, Preston (1989) finds that there is a wage difference between the workers in the for-profit organizations and those in the nonprofit organizations and that most of the difference exists because the nonprofit workers engage in "labor donations." Also, Carpenter and Myers (2007) find that altruism and reputational concerns are positively associated with the decision to volunteer. Therefore, it is likely that the nonprofit CEOs choose to work in a nonprofit organization instead of a commercial firm because of reputation concerns. If the rating agency lists the nonprofit organization, the organization will have more public exposure. Therefore, the CEOs of the organization are more likely to have lower pay because of reputation concerns. My third hypothesis is:

H3: Nonprofit rating score is negatively associated with CEO pay-to-performance sensitivity.

As is mentioned above, Charity Navigator also provides two dimensions of ratings, financial and accountability. The financial rating measures financial efficiency and capacity using 
Charity Navigator's financial ratios, and accountability evaluates charity accountability and transparency.6 It might be the case that if directors of an organization have excellent performance financially, their intelligence and leadership skills can improve accountability as well. However, these two dimensions are not directly related to each other. Financial ratios are derived from the financial statements on Form 990, while accountability evaluates organization governance, and the information for accountability rating is from the answers to qualitative questions on Form 990 or organization websites. Even though the overall hypothesis is that higher ratings are associated with CEO compensation, it is of interest to test whether financial and accountability ratings have different impacts on CEO compensation. Compared to accountability measures, which are qualitative measures that are easily available on organization websites, financial measures require professional evaluations beyond most donors. It is not cost-effective for most donors to evaluate on their own, and that most donors might not be capable of doing so. Therefore, financial measures are expected to play a more important role in reducing information asymmetry between nonprofit organizations and donors, and accountability measures might not play a role that is as important as financial measures. Therefore. my last two hypotheses, stated in the null form, are:

H4: Financial rating score/rank is negatively associated with CEO pay-to-performance sensitivity.

H5: Accountability rating score/rank is negatively associated with CEO pay-toperformance sensitivity.

\footnotetext{
${ }^{6}$ See https://www.charitynavigator.org/index.cfm?bay=content.view\&cpid=35 for financial rating and https://www.charitynavigator.org/index.cfm?bay=content.view\&cpid=1093 for accountability rating
} 


\subsection{SAMPLE AND MODELS:}

\subsection{Sample}

The compensation and fundamental data in this study are obtained from a database of efiled, IRS Form 990 returns from the years 2010 to 2017. The database was derived from the IRS cloud-based data warehouse of e-filed returns, stored on Amazon Web Services (Wu and Dull 2020). The IRS requires that nonprofit organizations disclose the compensation information for their officers, directors, trustees, key employees, highly compensated employees, and independent contractors in Part VII of Form 990. Therefore, the compensation information is obtained from Part VII of Form 990. The compensation data used in this paper include the compensation for all the individuals if their titles in the organizations contain "CEO," "Chief Executive Officer," "Director," or "President." Fundamental data needed for the study include total assets, total revenue, total program service expenses, and total CEO compensation, all from Form 990. The Form 990 database includes Form 990 information for the organizations that electronically filed only. Nonprofit organizations are classified by sector through the National Taxonomy of Exempt Entities (NTEE), and each organization is assigned to one of 26 sectors.

Following Gordon et al. (2009), this paper uses Charity Navigator as a rating agency because it is the only agency that provides historical rating records thereby enabling this study to include prior years in the analysis, and providing the largest possible sample size. Charity Navigator claims to be the largest and most used charity rating agency (Charity Navigator 2020) and rates about 9,000 nonprofit organizations annually. Charity Navigator evaluates nonprofit organizations based on two dimensions. the financial dimension assesses the financial health of the organization while the accountability dimension assesses the governance and ethics of the 
organization.7 For each dimension, Charity Navigator provides both a score (from 0-100) and rating rank (0-4 stars). The ranks correspond with the value of scores (see Figure 4.2). After the financial and accountability scores are determined, Charity Navigator uses a formula that includes the scores for the two dimensions to provides an overall score. Gordon et al. (2009), Harris and Neely (2016), nor any other prior study utilizes historical rating data from Charity Navigator. This paper, however, extracts historical rating information for the years 2010 to 2019 from the APIs provided by Charity Navigator using Python. The detailed data extracting procedure is illustrated in Appendix A.

\section{INSERT FIGURE 4.2}

Form 990 fundamental data were merged with the rating data from Charity Navigator by year and Employer Identification Number (EIN). A sample of 275,516 organization years from 51,441 organizations is obtained, including 18,436 rated organization years from 4,419 organizations.

\subsection{The models}

To examine the monitoring role of donors through charity rating agencies, it is of interest to test whether rated nonprofit organizations have lower CEO compensation than nonprofit organizations that are not rated by rating agencies $(\mathrm{H} 1)$. To mitigate size effects on CEO compensation, the model includes CEO compensation adjusted by total revenues as the dependent variable. The model also includes total assets adjusted by total revenues and total program spending as control variables. Nonprofit organization size is likely associated with compensation because higher larger nonprofit organizations can afford higher payments to their CEOs. Therefore, Model (1) in this study is as follows:

\footnotetext{
${ }^{7}$ See footnote 3 .
} 


$$
\begin{gathered}
C O M P / R E V_{i t}=\beta_{0}+\beta_{1} R A T E D_{i t}+\beta_{2} \text { Asset } / \text { Rev }+\beta_{3} \text { Pspending }+\beta_{4} \text { Sector Dummy }+ \\
\beta_{5} \text { Year dummy }+\mu_{t}+\tau_{i}+\xi_{i t}
\end{gathered}
$$

Where:
$C O M P / R E V$
$=\mathrm{CEO}$ compensation adjusted by total revenue in year $\mathrm{t}$;
RATED
$=$ A dummy variable that indicates whether the organization year is rated by Charity navigator, and $R A T E D=1$ if the organization year is rated, and 0 otherwise;
Asset/Rev $\quad=\quad$ Total assets adjusted by total revenue; and
Pspending/Rev $\quad=\quad$ Total program spending in year $\mathrm{t}$ adjusted by total revenue.

Prior literature uses pay-to-performance sensitivity to indicate monitoring of the organizations (Ke et al. 1999; and Aggarwal et al. 2002). Therefore, the second model includes the interaction terms between charity rating dummy variable and performance variables. Since Aggarwal et al. (2002) find evidence that nonprofit organization board size has a negative impact on pay-to-performance sensitivity, this model includes board size and the interaction terms between board size and performance measures to avoid omitted variable bias. The same variable and interaction terms are included in the models to test other hypotheses that test pay-toperformance sensitivity. To examine the impact of rating agencies on pay-to-performance sensitivity for nonprofit organizations (H2), Model (2) in this study is as follows:

$$
\begin{aligned}
& \% \triangle C O M P_{i t}=\beta_{0}+\beta_{1} \% \Delta R E V_{i t}+\beta_{2} \triangle Y I E L D_{i t}+\beta_{3} R A T E D_{i t}+\beta_{4} B O A R D_{i t} \\
& +\beta_{4}\left(\% \Delta R E V_{i t} \times R A T E D_{i t}\right)+\beta_{5}\left(\triangle Y I E L D_{i t} \times R A T E D_{i t}\right) \\
& +\beta_{6}\left(\% \triangle R E V_{i t} \times B_{O A R D_{i t}}\right)+\beta_{7}\left(\triangle Y I E L D_{i t} \times B_{O A R D_{i t}}\right)+\beta_{8} \operatorname{Ln}\left(\text { ASSETS }_{i t-1}\right. \\
& +\beta_{9}\left(\% \Delta R E V_{i t} \times \operatorname{Ln}(A S S E T S)_{i t-1}+\beta_{10}\left(\triangle Y I E L D_{i t} \times \ln (\text { ASSETS })_{i t-1}\right.\right. \\
& +\beta_{11} \text { Sector Dummy }+\beta_{12} \text { Year dummy } \\
& +\mu_{t}+\tau_{i}+\xi_{i t}
\end{aligned}
$$

Where:

$$
\begin{array}{ll}
\% \triangle C O M P & =\begin{array}{l}
\text { Percentage change in CEO compensation from year } \mathrm{t}-1 \text { to } \\
\text { year } \mathrm{t} ;
\end{array} \\
\% \triangle R E V & =\text { Percentage change in total revenue from year } \mathrm{t}-1 \text { to year } \mathrm{t} \\
\text { BOARD } & =\text { Board size of the organization year; }
\end{array}
$$




$\begin{array}{ll}\text { RATED }= & \begin{array}{l}\text { A dummy variable that indicates whether the organization } \\ \text { year is rated by Charity navigator, and } R A T E D=1 \text { if the } \\ \text { organization year is rated, and } 0 \text { otherwise; }\end{array} \\ \triangle Y \text { YIELD } \quad & \text { Fund usage performance; and } \\ \text { Ln(ASSETS } \quad=\quad \text { Natural log of total assets. }\end{array}$

Nonprofit organization CEO performance measures are $\% \triangle \mathrm{REV}$ and $\triangle \mathrm{YIELD}$, derived by Baber et al. (2002). Baber et al. (2002) argue that charities are brokers of funds from donors to beneficiaries, and the objective is to maximize program spending on program activities. Baber et al. (2002) then decompose percentage change in program spending as:

$$
\% \triangle P S P E N D I N G=\% \triangle R E V+\triangle Y I E L D
$$

In Model (3) \% $\triangle P S P E N D I N G$ is the percentage change in total program spending, \% $\triangle R E V$ is the percentage change in total revenue, and $\triangle Y^{\prime} I E L D_{t}=\left[R E V_{t} \times \triangle R A T I O_{t}\right] / P S P E N D I N G_{t-1}$. In the two portions of program spending change, $\% \triangle R E V$ indicates the change in fundraising performance, and $\triangle Y I E L D$ indicates the change in brokering's average cost contributed capital from contributors to beneficiaries. Baber et al. (2002) find that these two performance measures are positively associated with compensation.

Following Aggarwal et al. (2012), this model includes the interaction terms between performance measure and the primary variable of interest in this study, namely RATED. The coefficients of the interaction terms $\beta_{4}$ and $\beta_{5}$ are expected to be negative. If this is the case, it implies that the percentage increase in CEO compensation will be less for the rated organizations for the same improvement in performance. The model also includes the interaction terms between Ln(ASSETS) and performance measures to control any non-linear size effect between payperformance sensitivity and nonprofit size, following Aggarwal et al. (2012). Sector and year fixed effects are included in the model as $\mu_{\mathrm{t}}$ and $\tau_{\mathrm{i}}$. 
Charity Navigator does not include CEO compensation as a rating standard. Even though failure to provide $\mathrm{CEO}$ compensation will hurt the charity's accountability and transparency score, the compensation amount does not impact a charity's financial rating. Thus, including charity rating as an independent variable and compensation as a dependent variable should not result in an endogeneity issue.

$\mathrm{H} 3$ examines if the nonprofit rating score has a negative impact on CEO pay-toperformance sensitivity. Sloan (2008), Chen (2009), and Grant (2010) find evidence that donors use third-party information to make donation decisions. Moreover, Gordon et al. (2009) find that an increase in charity rating is associated with increased donations, and Harris and Neely (2016) find that higher ratings are associated with more donations. Even though donors' direct monitoring role is limited, public exposure will push the CEOs of nonprofit organizations to do what is right instead of seeking personal benefits.

Therefore, it is likely that higher ratings cause more public exposure for nonprofit organizations. To test H3, this study used Model (4) as follows:

$$
\begin{aligned}
& \% \triangle C O M P_{i t}=\beta_{0}+\beta_{1} \% \triangle R E V_{i t}+\beta_{2} \triangle Y I E L D_{i t}+\beta_{3} \operatorname{lnSCORE_{it}}+\beta_{4} B O A R D_{i t} \\
& +\beta_{5}\left(\% \triangle R E V_{i t} \times B O A R D_{i t}\right)+\beta_{6}\left(\triangle Y I E L D_{i t} \times B O A R D_{i t}\right) \\
& +\beta_{7}\left(\% \Delta R E V_{i t} \times \operatorname{LnSCORE}_{i t}\right)+\beta_{8}\left(\triangle Y I E L D_{i t} \times \operatorname{LnSCORE}_{i t}\right) \\
& +\beta_{9} \operatorname{Ln}(\text { ASSETS })_{i t-1}+\beta_{10}\left(\% \Delta R E V_{i t} \times \operatorname{Ln}(\text { ASSETS })_{i t-1}\right. \\
& +\beta_{11}\left(\triangle Y \text { YIELD } D_{i t} \times \operatorname{Ln}(\text { ASSETS })_{i-1}+\beta_{12} \text { Sector Dummy }+\beta_{13}\right. \text { Year dummy } \\
& +\mu_{t}+\tau_{i}+\xi_{i t}
\end{aligned}
$$

\begin{tabular}{|c|c|c|}
\hline$\% \triangle C O M P$ & $=$ & $\begin{array}{l}\text { Percentage change in CEO compensation from year } \mathrm{t}-1 \text { to } \\
\text { year } \mathrm{t} \text {; }\end{array}$ \\
\hline$\% \triangle R E V$ & $=$ & Percentage change in total revenue from year $\mathrm{t}-1$ to year $\mathrm{t}$ \\
\hline$\triangle Y I E L D$ & $=$ & Fund usage performance; and \\
\hline$B O A R D$ & $=$ & Board size of the organization year; \\
\hline LnSCORE & $=$ & Rating score by Charity Navigator; \\
\hline Ln(ASSETS) & $=$ & Natural log of total assets. \\
\hline
\end{tabular}

Where: 
Charity Navigator provides two dimensions of ratings, financial and accountability. While accountability captures qualitative measures that are easily available on organization websites, financial measures require professional evaluations beyond most donors. It is also not costefficient for most donors to reach out to the tax forms of nonprofit organizations. Therefore, financial ratings are likely to play a more important role in reducing information asymmetry between nonprofit organizations and donors as compared to accountability ratings. The model to test $\mathrm{H} 4$ and $\mathrm{H} 5$ is similar to the test for $\mathrm{H} 3$, and both financial and accountability ratings are included. Model (5) to test $\mathrm{H} 4$ and $\mathrm{H} 5$ is as follows:

$$
\begin{aligned}
& \% \triangle C O M P_{i t}=\beta_{0}+\beta_{1} \% \Delta R E V_{i t}+\beta_{2} \Delta Y I E L D_{i t}+\beta_{3} \text { LnFin }_{i t}+\beta_{4} L n A c c_{i t}+\beta_{5} B O A R D_{i t} \\
& +\beta_{6}\left(\% \Delta R E V_{i t} \times B_{\left.B O A R D_{i t}\right)}+\beta_{7}\left(\triangle Y I E L D_{i t} \times B O A R D_{i t}\right)\right. \\
& +\beta_{8}\left(\% \Delta R E V_{i t} \times L n F i n_{i t}\right)+\beta_{9}\left(\Delta Y I E L D_{i t} \times \operatorname{LnFin}_{i t}\right)+\beta_{10}\left(\% \Delta R E V_{i t} \times L n A c c_{i t}\right) \\
& +\beta_{11}\left(\triangle Y I E L D_{i t} \times \operatorname{LnAcc}_{i t}\right)+\beta_{12} \ln (\text { ASSETS })_{i t-1} \\
& +\beta_{13}\left(\% \Delta R E V_{i t} \times \operatorname{Ln}(\text { ASSETS })_{i t-1}+\beta_{14}\left(\Delta Y I E L D_{i t} \times \operatorname{Ln}(A S S E T S)_{i t-1}\right.\right. \\
& +\beta_{15} \text { Sector Dummy }+\beta_{16} \text { Year dummy } \\
& +\mu_{t}+\tau_{i}+\xi_{i t}
\end{aligned}
$$

Where:

$\begin{array}{ll}\% \triangle C O M P & \text { Percentage change in CEO compensation from year } \mathrm{t}-1 \text { to } \\ \% \triangle R E V & =\text { year } \mathrm{t} \text {; } \\ \triangle Y \text { YIELD } & =\text { Fund usage performance; and } \\ \text { BOARD } & =\text { Board size of the organization year; } \\ \text { LnFin } & =\text { Natural log of financial rating score by Charity Navigator; } \\ \text { LnAcc } & =\text { Natural log of accountability rating score by Charity } \\ \text { Ln(ASSETS }) & =\text { Navigator; }\end{array}$




\subsection{EMPIRICAL RESULTS}

\subsection{Descriptive statistics}

Descriptive statistics are shown in Table 4.1. The descriptive statistics for levels variables and change variables are presented in Panel A and Panel B, respectively. Panel A shows that there are 275,516 organization years included in the sample of this study. This sample is used to test H1 and $\mathrm{H} 2$, which involves the study on all nonprofit organizations with available data. However, the sample is reduced to only including rated organizations to test $\mathrm{H} 3, \mathrm{H} 4$, and $\mathrm{H} 5$. The rated sample includes 28,210 observations. Table 4.1 reports the descriptive statistics based on the overall sample. The average CEO compensation in this sample is $\$ 162,492$, with a median of 104,434 . The average total revenue of nonprofit organizations in this sample is about $\$ 75$ million, and the average program spending is about $\$ 59$ million. The average size of nonprofit organizations, measured by total assets is about $\$ 111$ million, with a min of $\$ 22,000$ and a max of $\$ 2,952$ million.

The descriptive statistics for the change variables are shown in Panel B of Table 4.1. Percentage change in CEO compensation is $10.7 \%$ on average, with a median of $2.7 \%$. The mean $\% \triangle R E V$ is $8.20 \%$, and the median is $3.9 \%$. $\triangle Y I E L D$ shows similar statistics to that of $\% \triangle R E V$, with a mean of $-1.20 \%$ and a median of $0.00 \% . \% \triangle P S P E N D I N G$ has a mean of $7 \%$ and a median of $3.90 \%$.

\section{INSERT TABLE 4.1}

Table 4.2 reports correlation coefficients between the variables of interest. Panel A presents the correlation coefficients between levels variables, and Panel B shows those between change variables. The compensation level variable is positively associated with total assets, total revenue, and total program spending. This is as expected because larger organizations (higher total assets) are expected to have more revenues and program spending. Also, Charity Navigator only provides 
ratings for larger organizations, so rated organizations should have higher compensations. This does not contradict with $\mathrm{H} 1$ since $\mathrm{H} 1$ will be tested using a regression model with control variables that might impact compensation as well. Detailed information will be given below in the regression result session. Panel B of Table 4.2 shows the correlation coefficients of the change variables. Change in compensation is positively associated with a change in CEO performance. This is consistent with the results in Baber et al. (2002).

\section{INSERT TABLE 4.2}

\subsection{Regression results}

H1 tests whether rated nonprofit organizations have higher compensation than non-rated organizations. To further facilitate the test, Figure 4.3 shows a trend of average CEO compensation for rated and non-rated organizations through the sample period. Figure 4.3 shows that even though CEO compensation adjusted by total revenues shows increasing trends for both rated and nonrated organizations, CEO compensation adjusted by total revenue has been higher for the nonprofit organizations that are not rated than that for the rated organizations, and the difference is more significant over time. This provides evidence that rated nonprofit organizations are likely under more monitoring than non-rated organizations, and the monitoring is likely from donors through nonprofit rating agencies.

Table 4.3 shows the regression results for Model (1) to test H1. Compensation adjusted by total revenue is the dependent variable. The main variable of interest is an indicator variable Rated, which equals 1 if the organization year has a rating record on Charity Navigator and 0 otherwise. Control variables include total assets adjusted by total revenue and total program spending. The coefficient on Rated is negative and significant $(-52.254)$ at the 1 percent level ( $\mathrm{t}$ statistics=32.947). This supports $\mathrm{H} 1$ that rated charities pay less in CEO compensation. Since donors dislike 
higher CEO compensation (Balsam and Harris 2014). This result likely indicates that donors play a monitoring role through rating agencies to lower CEO compensation.

\section{INSERT FIGURE 4.3}

\section{INSERT TABLE 4.3}

$\mathrm{H} 2$ in this study focuses on whether a rated charity is negatively associated with nonprofit organization pay-to-performance sensitivity. The dependent variable of this model is the percentage change in CEO compensation. Table 4.4 presents the regression results for Model (2). For $\mathrm{H} 2$, the variables of interest are the interaction terms between the charity rating dummy variable and the two performance measures. The coefficient for the interaction between rating dummy and change in revenues (yield) is $-0.127(-0.099)$, with a t-statistics of $-3.100(-2.863)$. This suggests that pay-to-performance sensitivity is lower for rated nonprofit organizations. While Baber et al. (2002) find evidence that CEO performance is associated with CEO compensation, the magnitude of the increase in CEO compensation with the same level of increase in performance indicates the effectiveness of the monitoring roles of other parties, and lower pay-to-performance sensitivity implies more effective monitoring of the organization. Research on both for-profit and nonprofit organizations have applied this concept to test monitoring role (Ke et al. 1999; Aggarwal et al. 2012). Therefore, lower pay-to-performance sensitivity for the rated nonprofit organizations suggests that monitoring for rated organizations is likely stronger, and this monitoring is likely from donors since they have the incentive to do so and rating agencies provide them with the channel to play this role.

\section{INSERT TABLE 4.4}

As is discussed above, nonprofit organizations with higher rating scores are likely to have more public exposure. Charity Navigator provides a sorted list of nonprofit organizations, and it 
is rational to assume that donors are more likely to search nonprofit organizations with higher ratings. In fact, prior research has found that a higher rating is associated with more donations, and an increase in rating score is followed by more donations (Gordon et al. 2009; Harris and Neely 2016). To test whether a charity rating score is associated with pay-to-performance sensitivity (H3), the rating dummy variable is replaced with the natural log of the actual rating score to obtain Model (4). Table 4.5 presents the regression results of this analysis. The interaction term's coefficient between the natural log of rating score and percentage change in revenues is -0.840 with a t-statistics of -2.752 . The interaction term's coefficient between the natural log of rating score and change in yield is -0.576 , with a t-statistics of -1.887 and marginally significant at the 10 percent level. Therefore, $\mathrm{H} 3$ is supported. As is explained above, lower pay-to-performance sensitivity implies more effective monitoring. Therefore, the negative coefficient of the interaction term between rating scores and performance measures indicates that highly-rated organizations are under more effective monitoring, and the monitoring is likely from donors since highly-rated organizations have more public exposure and their information is more accessible to donors.

\section{INSERT TABLE 4.5}

$\mathrm{H} 4$ tests whether financial rating reduces information asymmetry between donors and nonprofit organizations, while $\mathrm{H} 5$ tests the effect of accountability rating information. The financial rating evaluates nonprofit organizations' financial performance based on the financial information on Form 990, while the accountability rating evaluates some qualitative characteristics of nonprofit organizations such as organization government. Accountability measures are evaluated based on the information from the website, so accountability information is likely more accessible for donors. On the other hand, not all donors are able to interpret the information from Form 990 (Balsam and Harris 2014). Model (5) includes interaction terms between the two rating 
scores (financial and accountability) and the two performance measures (revenue and yield). The coefficient of the interaction term between the natural log of financial (accountability) rating score and change in revenue is $-0.482(-0.418)$, with t-statistics of $-2.528(-1.282)$. The coefficient of the interaction terms between the natural log of financial (accountability) rating score and change in yield is $-0.567(0.227)$, with t-statistics of $-2.790(-0.687)$. Overall, the interaction terms' coefficients between the natural log of financial rating scores and performance measures are significant, while those for the interactions between accountability scores and performance measures are not significant. Thus, H4 is supported and H5 is rejected. Since accountability information is more accessible and understandable by donors (i.e. board listing, Form 990 availability, or privacy policy), it is likely that donors do not need rating information to monitor nonprofit organizations. On the other hand, the financial rating is based on ratio analysis on the financial reports, which requires professional techniques. Therefore, it is more likely that donors rely on charity ratings to monitor. Results from this model indicate that financial rating score affects pay-to-performance sensitivity, while accountability rating score does not have the effect, thus providing evidence that donors use charity rating information to play the monitoring role.

\section{INSERT TABLE 4.6}

\section{Additional analysis:}

To further examine the impact of charity rating on pay-to-performance sensitivity, this study includes an additional analysis that explores whether pay-to-performance sensitivity is different for the same organization before and after the organization is rated by Charity Navigator. To construct the sample, the first step is to identify organizations with at least one year of rating by Charity Navigator. The compensation and fundamental data of all organization years available from the Form 990 database are then matched to the organization identified in the first step. 
Another variable Ratedyr is created equal to 1 if the organization year has a rating record with Charity Navigator and 0 otherwise. The model for this additional analysis is the same as Model (2), except that RATED is replaced with RATEDYR, and the sample of the additional analysis includes the organization with at least one rating record with Charity Navigator. Model (6) is as follows:

$$
\begin{aligned}
& \% \triangle C O M P_{i t}=\beta_{0}+\beta_{1} \% \Delta R E V_{i t}+\beta_{2} \Delta Y I E L D_{i t}+\beta_{3} R A T E D Y R_{i t}+\beta_{4} B O A R D_{i t} \\
& +\beta_{4}\left(\% \Delta R E V_{i t} \times R A T E D Y R_{i t}\right)+\beta_{5}\left(\Delta Y I E L D_{i t} \times R A T E D Y R_{i t}\right) \\
& +\beta_{6}\left(\% \triangle R E V_{i t} \times B O A R D_{i t}\right)+\beta_{7}\left(\triangle Y I E L D_{i t} \times B O A R D_{i t}\right)+\beta_{8} \operatorname{Ln}(\text { ASSETS })_{i t-1} \\
& +\beta_{9}\left(\% \Delta R E V_{i t} \times \operatorname{Ln}(A S S E T S)_{i t-1}+\beta_{10}\left(\triangle Y I E L D_{i t} \times \ln (\text { ASSETS })_{i t-1}\right.\right. \\
& +\beta_{11} \text { Sector Dummy }+\beta_{12} \text { Year dummy } \\
& +\mu_{t}+\tau_{i}+\xi_{i t}
\end{aligned}
$$

\begin{tabular}{|c|c|c|}
\hline$\% \triangle C O M P$ & $=$ & $\begin{array}{l}\text { Percentage change in CEO compensation from year } t-1 \text { to } \\
\text { year } t \text {; }\end{array}$ \\
\hline$\% \triangle R E V$ & $=$ & Percentage change in total revenue from year $t-1$ to year $t$ \\
\hline$B O A R D$ & $=$ & Board size of the organization year; \\
\hline$R A T E D Y R$ & $=$ & $\begin{array}{l}\text { A dummy variable that indicates whether the organization } \\
\text { year is rated by Charity navigator, and } R A T E D Y R=1 \text { if the } \\
\text { organization year is rated, and } 0 \text { otherwise; }\end{array}$ \\
\hline$\triangle Y I E L D$ & $=$ & Fund usage performance; and \\
\hline $\operatorname{Ln}(A S S E T S)$ & $=$ & Natural log of total assets. \\
\hline
\end{tabular}

Where:

Additional analysis results are presented in Table 4.7. The coefficients for the interaction terms between RATEDYR and performance measures are negative and significant at 5 percent level. This suggests that for the same organizations that have both rated and non-rated records, the rated organization years have lower pay-to-performance sensitivity. In other words, a performance improvement is associated with a lower increase in payment if the organization year is rated. Therefore, results from this model provide additional evidence that charity rating likely plays an important role as the media for donors to monitor nonprofit organizations. 


\section{INSERT TABLE 4.7}

\subsection{DISCUSSION}

This study investigates the association between charity rating and nonprofit pay-toperformance sensitivity. Because donors have incentives to monitor nonprofit organizations and charity rating agencies reduce information asymmetry between donors and nonprofit organizations, the association between charity rating and pay-to-performance sensitivity likely indicates external monitoring on nonprofit organizations by donors through charity rating agencies. To facilitate this study, the first hypothesis of this paper is to test whether rated organizations have lower CEO compensations (adjusted by total revenue) overall. Regression results show that the coefficient of Rated is negative, which implies that rated organizations have lower CEO compensation (adjusted by total revenue) overall. This provides initial evidence that charity rating is likely associated with the monitoring of nonprofit organizations.

The main test in this study is the second hypothesis, which examines whether rated organizations have a lower pay-to-performance sensitivity. The empirical result sees negative coefficients for the interactions between performance measures and the rating indicator. This suggests that for a rated organization, the magnitude of the increase in CEO compensation is lower as compared to that of a non-rated organization. Donors dislike higher payments, and this lower increase in payments likely indicates donors monitoring role on nonprofit organizations. The results of this test complement prior research by providing evidence of external monitoring by donors.

Higher-rated organizations likely have more public exposure because of the easy access to their information if donors sort or check the "top" lists. Therefore, if higher-rated organizations have lower pay-to-performance sensitivity, it will provide further evidence of donors' monitoring 
of nonprofit organizations. The coefficient of the interaction terms between performance measures and rating score is significantly negative, which implies that an increase in CEO performance is associated with an increase in CEO compensation to a lesser extent for higher-rated organizations, compared to lower-rated organizations. Therefore, the results from this model support the argument that donors likely monitor nonprofit organizations through the use of charity rating information.

Charity Navigator provides charity ratings in two dimensions, financial and accountability. Since accountability information is more accessible and understandable for donors. Financial rating scores likely affect monitoring, while accountability not. Therefore, the next hypothesis tests whether financial rating scores are associated with pay-to-performance sensitivity. Empirical results show negative coefficients for the interaction terms between financial scores and performance measures, thus providing additional evidence of donors' use of rating information to monitor nonprofit organizations.

To provide further evidence of donors' monitoring role on nonprofit organizations through charity rating agencies, this study includes an additional analysis, which examines whether payto-performance sensitivity is lower for rated organization years compared to that for non-rated organization years for the organizations that have at least one of rating record with Charity Navigator. Results show negative coefficients for the interaction terms between rated-year indicator and performance measures. This adds to the evidence of donors' use of rating information and monitoring role through the rating agencies.

\subsection{CONCLUSION}

The purpose of this study is to examine whether donors play a monitoring role to nonprofit organizations through charity rating agencies. To study this monitoring role, this study uses pay- 
to-performance sensitivity to indicate monitoring effectiveness. This proxy has been used in studies in both for-profit and nonprofit organizations (Ke et al. 1999; Aggarwal et al. 2012). Baber et al. (2002) find a positive association between nonprofit organization CEO performance and compensation. However, the magnitude of the increase in CEO compensation following an improvement of performance indicates the differences in monitoring effectiveness. Donors dislike higher CEO payments (Balsam and Harris 2014; Balsam and Harris 2018). Therefore, a lower payto-performance sensitivity is expected under donors' scrutiny. Aggarwal et al. (2012) find lower pay-to-performance sensitivity for nonprofit organizations with a larger board, which provides evidence of nonprofit board's monitoring. This paper, however, focuses on the external monitoring role by donors.

Empirically, this study examines whether pay-to-performance sensitivity is lower for rated organizations compared to non-rated organizations, and lower for higher-rated organizations compared to lower-rated organizations. Rating agencies reduce information asymmetry between donors and nonprofit organizations by providing ratings based on the analysis of financial and accountability attributes of nonprofit organizations. Since accountability information is more accessible to donors compared to financial information, accountability rating is not expected to affect pay-to-performance sensitivity as financial rating does.

The sample of this study is from Form 990 of nonprofit organizations and Charity Navigator. Using models developed based on those in Baber et al. (2002) and Aggarwal et al. (2012), this study finds that pay-to-performance sensitivity is lower for rated organizations, highly rated organizations, and organizations with higher financial rating.

This paper contributes to the accounting literature in the following ways. First, this study provides evidence that charity rating is associated with the monitoring of nonprofit organizations. 
Since donors have incentives to monitor nonprofit organizations, and donors use rating information to make decisions, donors likely play a monitoring role through charity rating agencies. Aggarwal et al. (2012) find evidence of nonprofit organizations' insider governance role, but this study complements nonprofit organizations' monitoring by finding evidence of external monitoring on nonprofit organizations. Second, this study complements the literature on charity rating and finds that charity rating is associated with nonprofit organizations' pay-to-performance sensitivities. The results provide additional evidence that donors use third-party information to make decisions. Last, this paper adds to the nonprofit organization governance and monitoring literature and finds that charity rating agencies' role as information intermediaries also contributes to the external monitoring of nonprofit organizations. 


\section{References:}

Aggarwal, R. K., M. E. Evans, and D. Nanda. 2012. Nonprofit boards : Size, performance and managerial incentives \$. Journal of Accounting and Economics 53 (1-2): 466-487.

Baber, W.R., Daniel, P.L. and Roberts, A.A. 2002. Compensation to managers of charitable organizations: An empirical study of the role of accounting measures of program activities. The Accounting Review 77(3): 679-693.

Balsam, S., and E. E. Harris. 2014. The Impact of CEO Compensation on Nonprofit Donations. The Accounting Review 89 (2): 425-450.

- 2018. Nonprofit executive incentive pay. Review of Accounting Studies 23: 1665-1714.

Banjo, S. 2009. IRS questions pay of charity executives. Wall Street Journal Online (February 18).

Bebchuk, L.A. and Fried, J.M. 2003. Executive compensation as an agency problem. Journal of economic perspectives 17(3): 71-92.

Brickley, J.A., Van Horn, R.L. and Wedig, G.J. 2003. Board structure and executive compensation in nonprofit organizations: Evidence from hospitals. Organizational Economics of Health Care Conference, Simon Graduate School of Business Administration Rochester, NY.

Boroff, P. 2008. Big bucks for theater chiefs draw criticism as sign of excess. Available at: http://www.bloomberg.com/apps/news?pid=newsarchive\&sid=aNSaiFBlWL9A\&refer=m

Callen, J.L., Klein, A. and Tinkelman, D. 2003. Board composition, committees, and organizational efficiency: The case of nonprofits. Nonprofit and voluntary sector quarterly 32(4): 493-520.

Carpenter, J. and Knowles Myers, C. 2007. Why volunteer? Evidence on the role of altruism, reputation, and incentives. Working paper

Charity Navigator. 2020. Available online at http://www.charitynavigator.org/, retrieved September 30, 2020.

Charity Navigator. 2020. Available online at http://www.charitynavigator.org/index.cfm?bay =con- tent.view\&cpid=32\#.U0mZZPldV8E, retrieved April 12, 2020. 
Chen, G. 2009. Does meeting standards affect charitable giving? An empirical study of New York metropolitan area charities. Nonprofit Management and Leadership 19 (3): 349-65.

Core, J. E., W. R. Guay, and R. S. Verdi. 2006. Agency problems of excess endowment holdings in not-for-profit firms. Journal of Accounting and Economics 41 (3): 307-333.

Fama, E. F., and M. C. Jensen. 1983. Separation of ownership and control. Journal of Law \& Economics 26: 301-325.

Fisman, R., and R. G. Hubbard. 2003. Title: The Role of Nonprofit Endowments The Role of Nonprofit Endowments. The Governance of Not-for-Profit Organizations I (January).

Gaver, J.J. and Im, S.M. 2014. Funding sources and excess CEO compensation in not-for-profit organizations. Accounting Horizons 28(1): 1-16.

Gershman, J. 2011. Charity probe questions. Wall Street Journal (September 9): A.21.

Gordon, T. P., C. L. Knock, and D. G. Neely. 2009. The role of rating agencies in the market for charitable contributions: An empirical test. Journal of Accounting and Public Policy 28 (6): $469-484$.

Grant, L. E. 2010. The response to third-party ratings: Evidence of the effects on charitable contributions. Unpublished manuscript, University of California Santa Barbara.

Harris, E. E., and D. G. Neely. 2016. Multiple Information Signals in the Market for Charitable Donations. Contemporary Accounting Research 33 (3): 989-1012.

Jensen, M.C. and Meckling, W.H. 1976. Theory of the firm: Managerial behavior, agency costs and ownership structure. Journal of financial economics 3(4): 305-360.

Ke, B., Petroni, K. and Safieddine, A. 1999. Ownership concentration and sensitivity of executive pay to accounting performance measures: Evidence from publicly and privately-held insurance companies. Journal of Accounting and Economics 28(2): 185-209.

Klein, A. 2002. Audit committee, board of director characteristics, and earnings management. Journal of accounting and economics 33(3): 375-400.

Mehran, H. 1995. Executive compensation structure, ownership, and firm performance. Journal of financial economics 38(2): 163-184. 
O'Regan, K. and Oster, S.M. 2005. Does the structure and composition of the board matter? The case of nonprofit organizations. Journal of Law, Economics, and Organization 21(1): 205227.

Preston, A. E. 1989. The nonprofit worker in a for-profit world. Journal of Labor Economics 7 (4): $438-463$.

Sloan, M. F. 2008. The effects of nonprofit accountability ratings on donor behavior. Nonprofit and Voluntary Sector Quarterly 38 (2): 220-36.

Tinkelman, D. 1998. Differences in sensitivity of financial statement users to joint cost allocations: The case of nonprofit organizations. Journal of Accounting, Auditing \& Finance 13(4): 377393.

Wilhelm, I. 2009. Executive compensation at charities attracts new scrutiny. The Chronicle of Philanthropy (February 18).

Wu, C. and Dull, R.B. 2020. Accessing Cloud Data to Expand Research and Analytical Opportunities: An Example using IRS/AWS Data for Nonprofit OrganizationsAccessing IRS/AWS Data for Nonprofit Organization Analysis. Journal of Emerging Technologies in Accounting. https://doi.org/10.2308/JETA-18-12-29-28

Yetman, M.H. and Yetman, R.J. 2013. Do donors discount low-quality accounting information? The Accounting Review 88(3): 1041-1067. 


\section{Appendix -How to obtain historical ratings data from Charity Navigator API}

The current ratings information is readily available by Charity Navigator, but the historical data is only available through Charity Navigator's API. The API is provided in an interactive window, as is shown in the picture below.

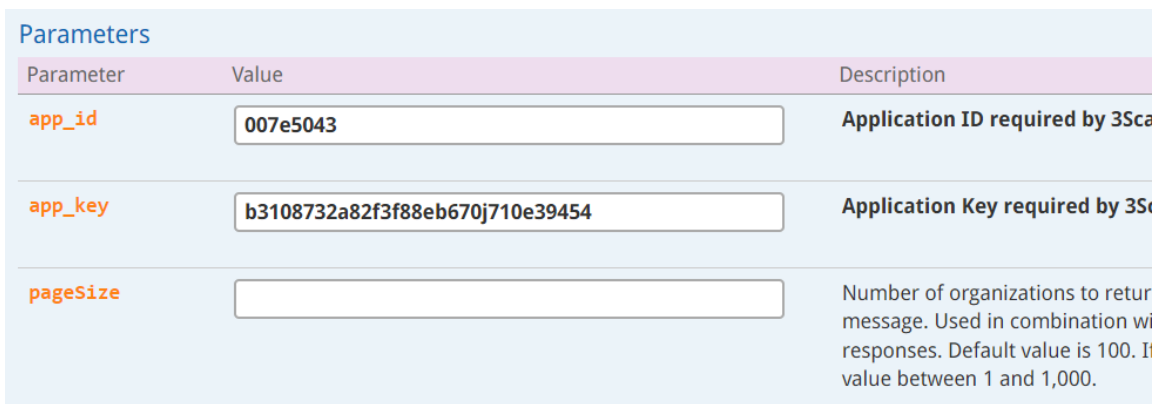

The URL is generated from the Charity Navigator API, Once the URLs are put in the internet browser, a .json file is generated and can be copied and saved as a .txt file. 8,960 URLs were generated through EIN (Employer Identification Number) for historical rating scores and ranks. These ratings are for the overall rating only. For each rating record (a combination of EIN and rating data), a unique Rating ID provided. The Charity Navigator API requires both the Rating ID and the EIN to generate the URLs for the two dimensions of rating (financial and accountability). 107,000 combinations are generated for the two dimensions and obtained about 7,300 records. Python codes were developed to open up the URLs and extract data from the .json files, because of the high number of URLs and the irregular format of the .json file. The Charity Navigator API has a limit of 25,000 hits per day, so the extraction of the data takes about five days, consistently running the Python codes. The Python codes then generate an excel file with the overall as well as financial and accountability rating scores and ranks. 


\section{Figure 4.1 Theoretical Framework}

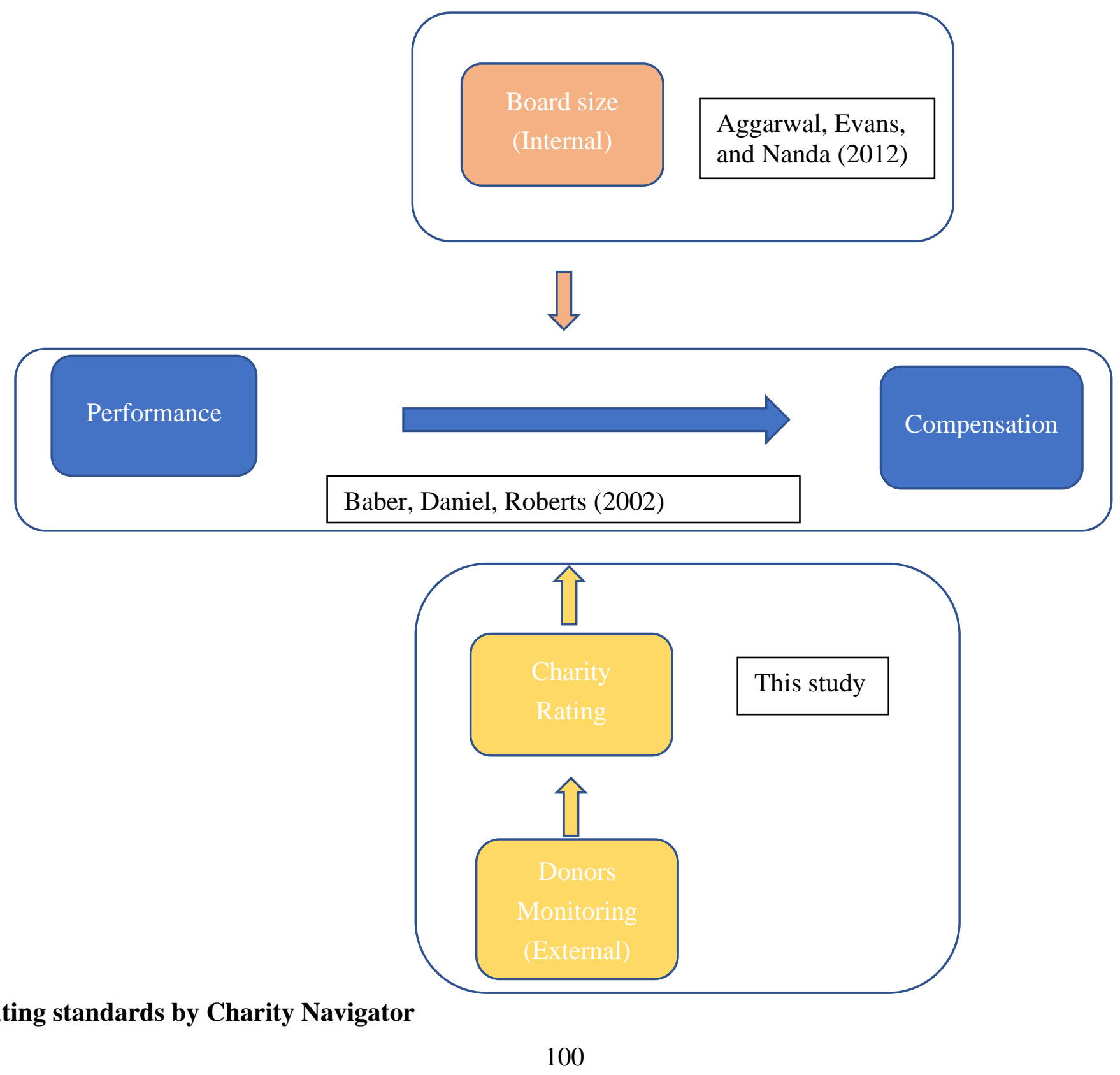




\begin{tabular}{cc}
\hline Overall score & Overall rating \\
\hline 290 & $\star \star \star \star$ \\
$80-90$ & $\star \star \star$ \\
$70-80$ & $\star \star$ \\
$55-70$ & $\star$ \\
$<55$ & 0 stars \\
\hline
\end{tabular}


Figure 4.3 Trend of CEO compensation (CEO compensation adjusted by total revenue)

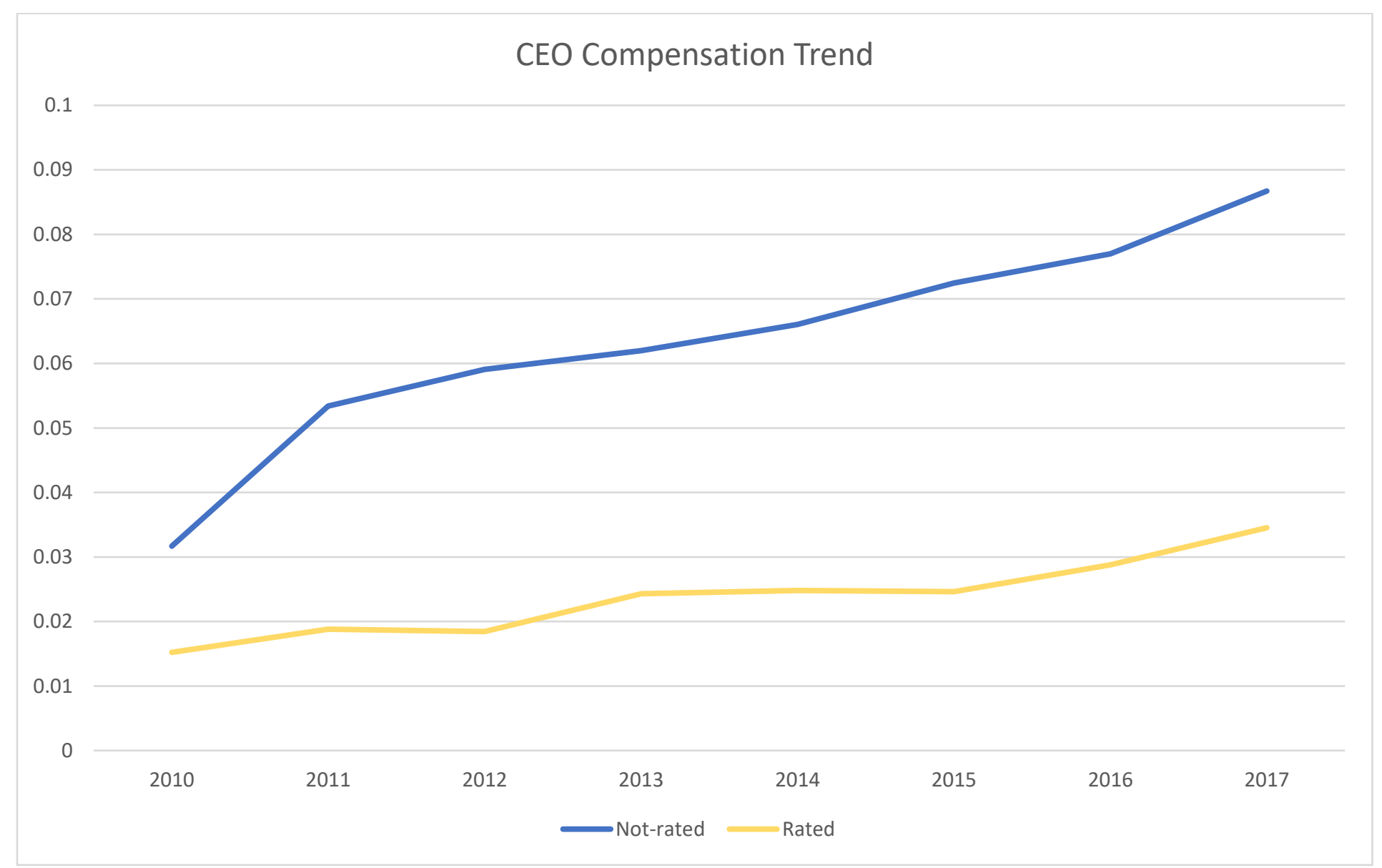


Table 4.1 Descriptive Statistics

\begin{tabular}{|c|c|c|c|c|c|c|}
\hline Panel A & $\mathbf{n}$ & mean & SD & p25 & Median & p75 \\
\hline \multicolumn{7}{|l|}{ Levels } \\
\hline \multicolumn{7}{|l|}{ Variables } \\
\hline СOMP & 275,516 & 162,492 & 188,629 & 65,000 & 104,434 & 177,337 \\
\hline ASSETS (in 1000's) & 275,516 & 111,805 & 411,227 & 751 & 3,777 & 22,554 \\
\hline $\begin{array}{c}\text { PSPENDING (in } \\
1000 \text { 's) }\end{array}$ & 275,515 & 59,345 & 249,098 & 611 & 2,467 & 14,207 \\
\hline REV (in 1000's) & 275,516 & 74,634 & 315,454 & 813 & 3,206 & 17,810 \\
\hline LnScore & 29,955 & 4.466 & 0.08 & 4.42 & 4.479 & 4.529 \\
\hline LnFin & 29,452 & 4.442 & 0.106 & 4.377 & 4.458 & 4.527 \\
\hline LnAcc & 29,491 & 4.522 & 0.088 & 4.489 & 4.533 & 4.605 \\
\hline \multicolumn{7}{|l|}{ Panel B } \\
\hline \multicolumn{7}{|l|}{ Changes } \\
\hline \multicolumn{7}{|l|}{ Variables } \\
\hline$\% \triangle C O M P$ & 275,516 & $10.70 \%$ & $44.90 \%$ & $0.00 \%$ & $2.70 \%$ & $8.90 \%$ \\
\hline$\% \Delta R E V$ & 275,489 & $8.20 \%$ & $32.60 \%$ & $-4.70 \%$ & $3.90 \%$ & $14.00 \%$ \\
\hline$\triangle Y I E L D$ & 263,183 & $-1.20 \%$ & $30.80 \%$ & $-7.10 \%$ & $0.00 \%$ & $7.20 \%$ \\
\hline$\% \triangle P S P E N D I N G$ & 263,183 & $7.00 \%$ & $24.10 \%$ & $-2.80 \%$ & $3.90 \%$ & $12.00 \%$ \\
\hline
\end{tabular}




\section{Table 4.2 Correlation Coefficient}

\begin{tabular}{lccccc}
$\begin{array}{l}\text { Panel A } \\
\text { Levels } \\
\text { Variables }\end{array}$ & $\boldsymbol{C O M P}$ & ASSET & $\boldsymbol{R E V}$ & PSPENDING & $\boldsymbol{R A T E D}$ \\
\hline $\boldsymbol{C O M P}$ & 1.000 & & & \\
$\boldsymbol{A S S E T}$ & $0.640^{* * *}$ & 1.000 & & \\
$\boldsymbol{R E V}$ & $0.579^{* * *}$ & $0.842^{* * *}$ & 1.000 & 1.000 & \\
$\boldsymbol{P S P E N D I N G}$ & $0.581^{* * *}$ & $0.835^{* * *}$ & $0.993^{* * *}$ & $-0.031^{* * *}$ & 1.000 \\
$\boldsymbol{R A T E D}$ & $0.035^{* * *}$ & $0.014^{* * *}$ & $-0.028^{* * *}$ & &
\end{tabular}

$* \mathrm{p}<0.05, * * \mathrm{p}<0.01, * * * \mathrm{p}<0.001$

Panel B

\begin{tabular}{|c|c|c|c|c|c|c|c|}
\hline $\begin{array}{l}\text { Changes } \\
\text { Variables }\end{array}$ & $\% \triangle C O M P$ & $\% \triangle P S P E N D I N G$ & $\% \triangle R E V$ & AYIELD & ASSET & RATED & BOARD \\
\hline$\% \triangle C O M P$ & 1.000 & & & & & & \\
\hline$\% \triangle P S P E N D I N G$ & $0.075^{* * *} *$ & 1.000 & & & & & \\
\hline$\% \triangle R E V$ & $0.045^{* * *}$ & $0.418 * * *$ & 1.000 & & & & \\
\hline$\triangle Y Y I E L D$ & $0.013 * * *$ & $0.342 * * *$ & $-0.678 * * *$ & 1.000 & & & \\
\hline ASSET & $-0.008 * * *$ & $-0.015^{* * *}$ & $0.011 * * *$ & $-0.023 * * *$ & 1.000 & & \\
\hline RATED & $0.004 *$ & $-0.026 * * *$ & $-0.005^{*}$ & $-0.015^{* * *}$ & $0.198 * * *$ & 1.000 & \\
\hline BOARD & 0.003 & $-0.044 * * *$ & $-0.019^{* * *}$ & $-0.014 * * *$ & $0.617 * * *$ & $0.316^{* * *}$ & 1.000 \\
\hline
\end{tabular}

$* \mathrm{p}<0.05, * * \mathrm{p}<0.01, * * * \mathrm{p}<0.001$ 


\section{Table 4.3 Regression results for $\mathrm{H1}$}

\begin{tabular}{lc}
\hline VARIABLES & Comp/Rev \\
\hline Rated & $-52.662 * * *$ \\
& $(-33.147)$
\end{tabular}

Asset/Rev 2.731***

(5.430)

Pspending/Rev $\quad 9.850^{* * *}$

$(5.57)$

\begin{tabular}{lc} 
Intercept & $75.105^{* * *}$ \\
& -43.61 \\
\hline Observations & 274,781 \\
Adjusted R-squared & 0.138 \\
Sector FE & YES \\
Year FE & YES \\
\hline
\end{tabular}

Standard errors are clustered at organization level. 
Table 4.4 Regression results for $\mathrm{H} 2$

\begin{tabular}{|c|c|}
\hline VARIABLES & \%Comp \\
\hline \multirow[t]{2}{*}{ Rated } & 0.005 \\
\hline & $(-0.221)$ \\
\hline \multirow{2}{*}{$\% R E V$} & $0.517 * * *$ \\
\hline & $(-10.188)$ \\
\hline \multirow[t]{2}{*}{$\Delta$ Yield } & $0.427 * * *$ \\
\hline & $(-10.581)$ \\
\hline \multirow[t]{2}{*}{ Lnasset } & $-0.004 * * *$ \\
\hline & $(-3.461)$ \\
\hline \multirow[t]{2}{*}{ Board size } & $0.014 * *$ \\
\hline & $(-2.346)$ \\
\hline \multirow[t]{2}{*}{ Rated $* \%$ Rev } & $-0.127 * * *$ \\
\hline & $(-3.100)$ \\
\hline \multirow[t]{2}{*}{ Rated $*$ YYield } & $-0.099 * * *$ \\
\hline & $(-2.863)$ \\
\hline \multirow[t]{2}{*}{ Rated ${ }^{*}$ Lnasset } & 0.001 \\
\hline & $(-0.399)$ \\
\hline \multirow[t]{2}{*}{ Board $* \%$ Rev } & $-0.141 * * *$ \\
\hline & $(-7.414)$ \\
\hline \multirow[t]{2}{*}{ Board $* \Delta$ Yield } & $-0.117 * * *$ \\
\hline & $(-7.789)$ \\
\hline \multirow[t]{2}{*}{ Intercept } & $0.099 * * *$ \\
\hline & $(-6.626)$ \\
\hline Observations & 263,183 \\
\hline Adjusted R-squared & 0.013 \\
\hline Sector FE & YES \\
\hline Year FE & YES \\
\hline
\end{tabular}

Standard errors are clustered at organization level. 
Table 4.5 Regression results for $\mathrm{H3}$

\begin{tabular}{|c|c|}
\hline VARIABLES & $\%$ Comp \\
\hline \multirow[t]{2}{*}{$\% R E V$} & $4.352 * * *$ \\
\hline & -3.144 \\
\hline \multirow[t]{2}{*}{$\Delta$ Yield } & $3.131 * *$ \\
\hline & -2.386 \\
\hline \multirow[t]{2}{*}{ Lnasset } & -0.085 \\
\hline & $(-0.578)$ \\
\hline \multirow[t]{2}{*}{ Board size } & $0.033 * *$ \\
\hline & -2.526 \\
\hline \multirow[t]{2}{*}{ Board $* \%$ Rev } & $-0.202 * * *$ \\
\hline & $(-2.655)$ \\
\hline \multirow[t]{2}{*}{ Board $* \Delta$ Yield } & $-0.185^{* *}$ \\
\hline & $(-2.498)$ \\
\hline \multirow[t]{2}{*}{ LnScore } & -0.167 \\
\hline & $(-0.615)$ \\
\hline \multirow[t]{2}{*}{ LnScore*\%Rev } & $-0.840 * * *$ \\
\hline & $(-2.752)$ \\
\hline \multirow[t]{2}{*}{ Lnscore* $*$ Yield } & $-0.576^{*}$ \\
\hline & $(-1.887)$ \\
\hline \multirow[t]{2}{*}{ Lnscore*Lnasset } & 0.018 \\
\hline & -0.537 \\
\hline \multirow[t]{2}{*}{ Intercept } & 0.782 \\
\hline & -0.643 \\
\hline Observations & 28,210 \\
\hline Adjusted R-squared & 0.021 \\
\hline Sector FE & YES \\
\hline Year FE & YES \\
\hline
\end{tabular}

Standard errors are clustered at organization level. 
Table 4.6 Regression results for $\mathrm{H4}$ and $\mathrm{H5}$

\begin{tabular}{|c|c|}
\hline VARIABLES & $\%$ Comp \\
\hline \multirow[t]{2}{*}{$\% R E V$} & $4.628 * * *$ \\
\hline & $(-2.634)$ \\
\hline \multirow[t]{2}{*}{$\Delta$ Yield } & 2.073 \\
\hline & $(-1.247)$ \\
\hline \multirow[t]{2}{*}{ Lnasset } & 0.107 \\
\hline & $(-0.554)$ \\
\hline \multirow[t]{2}{*}{ Board size } & $0.032 * *$ \\
\hline & $(-2.393)$ \\
\hline \multirow[t]{2}{*}{ Board $* \%$ Rev } & $-0.202 * * *$ \\
\hline & $(-2.660)$ \\
\hline \multirow[t]{2}{*}{ Board*AYield } & $-0.190 * * *$ \\
\hline & $(-2.813)$ \\
\hline \multirow[t]{2}{*}{ LnFin } & -0.326 \\
\hline & $(-1.598)$ \\
\hline \multirow[t]{2}{*}{$\operatorname{LnAcc}$} & $0.535^{*}$ \\
\hline & $(-1.82)$ \\
\hline \multirow[t]{2}{*}{ LnFin*\%Rev } & $-0.482 * *$ \\
\hline & $(-2.528)$ \\
\hline \multirow[t]{2}{*}{ LnFin* $\triangle$ Yield } & $-0.567 * * *$ \\
\hline & $(-2.790)$ \\
\hline \multirow[t]{2}{*}{ LnFin*Lnasset } & 0.035 \\
\hline & $(-1.511)$ \\
\hline \multirow[t]{2}{*}{ LnAcc*\%Rev } & -0.418 \\
\hline & $(-1.282)$ \\
\hline \multirow[t]{2}{*}{ LnAcc* $\triangle$ Yield } & 0.227 \\
\hline & $(-0.687)$ \\
\hline
\end{tabular}




\begin{tabular}{lc} 
LnAcc*Lnasset & $-0.059^{*}$ \\
& $(-1.648)$ \\
Intercept & -0.934 \\
& $(-0.614)$ \\
\hline Observations & 27,734 \\
Adjusted R-squared & 0.023 \\
Sector FE & YES \\
Year FE & YES \\
\hline
\end{tabular}

Standard errors are clustered at organization level. 
Table 4.7 Regression results for additional analysis

\begin{tabular}{lc}
\hline VARIABLES & \%omp \\
\hline Ratedyr & 0.027 \\
& $(0.444)$ \\
\%REV & $0.682 * * *$
\end{tabular}

(2.799)

AYield

$0.604 * * *$

(2.719)

Lnasset

$-0.004$

$(-0.614)$

Board size

$0.027 * *$

(2.315)

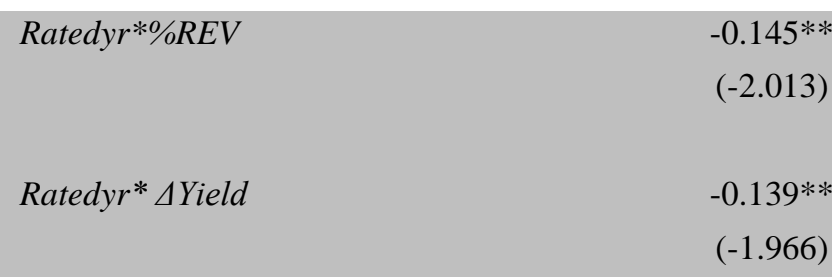

Rratedyr*Lnasset

$-0.001$

$(-0.187)$

$\% R E V^{*}$ Board

$-0.182 * *$

$(-2.472)$

AYield *Board

$-0.156^{* *}$

$(-2.257)$

Intercept

0.036

(0.601)

\begin{tabular}{lc}
\hline Observations & 32,903 \\
Adjusted R-squared & 0.016 \\
Sector FE & YES \\
Year FE & YES \\
\hline
\end{tabular}

Standard errors are clustered at organization level. 